\title{
Structure of a normal seismogenic fault zone in carbonates: The Vado di Corno Fault, Campo Imperatore, Central Apennines (Italy)
}

DOI:

10.1016/j.jsg.2016.08.004

\section{Document Version}

Accepted author manuscript

Link to publication record in Manchester Research Explorer

Citation for published version (APA):

Demurtas, M., Fondriest, M., Balsamo, F., Clemenzi , L., Storti , F., Bistacchi , A., \& Di Toro, G. (2016). Structure of a normal seismogenic fault zone in carbonates: The Vado di Corno Fault, Campo Imperatore, Central Apennines (Italy). Journal of Structural Geology, 90, 185-206. https://doi.org/10.1016/j.jsg.2016.08.004

\section{Published in:}

Journal of Structural Geology

\section{Citing this paper}

Please note that where the full-text provided on Manchester Research Explorer is the Author Accepted Manuscript or Proof version this may differ from the final Published version. If citing, it is advised that you check and use the publisher's definitive version.

\section{General rights}

Copyright and moral rights for the publications made accessible in the Research Explorer are retained by the authors and/or other copyright owners and it is a condition of accessing publications that users recognise and abide by the legal requirements associated with these rights.

\section{Takedown policy}

If you believe that this document breaches copyright please refer to the University of Manchester's Takedown Procedures [http://man.ac.uk/04Y6Bo] or contact uml.scholarlycommunications@manchester.ac.uk providing relevant details, so we can investigate your claim.

\section{OPEN ACCESS}




\section{Accepted Manuscript}

Structure of a normal seismogenic fault zone in carbonates: The Vado di Corno Fault, Campo Imperatore, Central Apennines (Italy)

Matteo Demurtas, Michele Fondriest, Fabrizio Balsamo, Luca Clemenzi, Fabrizio Storti, Andrea Bistacchi, Giulio Di Toro

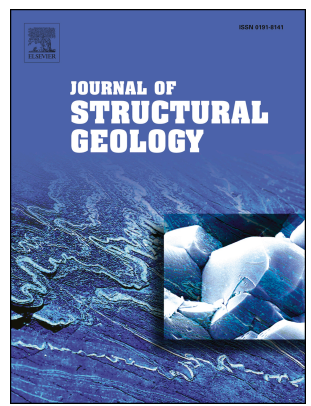

PII: S0191-8141(16)30106-7

DOI: 10.1016/j.jsg.2016.08.004

Reference: $\quad$ SG 3372

To appear in: Journal of Structural Geology

Received Date: 13 February 2016

Revised Date: 8 August 2016

Accepted Date: 8 August 2016

Please cite this article as: Demurtas, M., Fondriest, M., Balsamo, F., Clemenzi, L., Storti, F., Bistacchi, A., Di Toro, G., Structure of a normal seismogenic fault zone in carbonates: The Vado di Corno Fault, Campo Imperatore, Central Apennines (Italy), Journal of Structural Geology (2016), doi: 10.1016/ j.jsg.2016.08.004.

This is a PDF file of an unedited manuscript that has been accepted for publication. As a service to our customers we are providing this early version of the manuscript. The manuscript will undergo copyediting, typesetting, and review of the resulting proof before it is published in its final form. Please note that during the production process errors may be discovered which could affect the content, and all legal disclaimers that apply to the journal pertain. 
1 Structure of a normal seismogenic fault zone in carbonates: the Vado di Corno Fault,

2 Campo Imperatore, Central Apennines (Italy)

4 Matteo Demurtas $^{\mathrm{a} *}$, Michele Fondriest ${ }^{\mathrm{b}}$, Fabrizio Balsamo ${ }^{\mathrm{c}}$, Luca Clemenzi ${ }^{\mathrm{c}}$, Fabrizio Storti ${ }^{\mathrm{c}}$, $5 \quad$ Andrea Bistacchi ${ }^{\mathrm{d}}$, Giulio Di Toro ${ }^{\mathrm{a}, \mathrm{b}, \mathrm{e}}$

${ }^{\text {a }}$ Dipartimento di Geoscienze, Università degli Studi di Padova, Via G. Gradenigo 6, 35131 Padova, 8 Italy

$9{ }^{\mathrm{b}}$ School of Earth, Atmospheric and Environmental Sciences, University of Manchester, M13 9PL, 10 UK

$11{ }^{c}$ NEXT - Natural and Experimental Tectonics Research Group - Università degli Studi di Parma, 12 Dipartimento di Fisica e Scienze della Terra "Macedonio Melloni”, 43124 Parma, Italy ${ }^{\mathrm{d}}$ Department of Earth and Environmental Sciences, Università degli Studi di Milano Bicocca, 14 Piazza della Scienza 4, 20126 Milan, Italy ${ }^{\mathrm{e}}$ Istituto Nazionale di Geofisica e Vulcanologia (INGV), Via di Vigna Murata 605, 00143 Roma, 16 Italy

* Corresponding author: Matteo Demurtas, Dipartimento di Geoscienze, Via G. Gradenigo 6, 35131

Padova, Italy (matteo.demurtas@ studenti.unipd.it), +39 3467589339

E-mail address other authors: michele.fondriest@manchester.ac.uk (Michele Fondriest); luca.clemenzi@gmail.com (Luca Clemenzi); fabrizio.balsamo@unipr.it (Fabrizio Balsamo); fabrizio.storti@unipr.it (Fabrizio Storti); andrea.bistacchi@unimib.it (Andrea Bistacchi); giulio.ditoro@manchester.ac.uk (Giulio Di Toro)

Keywords: earthquake; Central Apennines; carbonate; fault zone; fault rock; 
Abstract

The Vado di Corno Fault Zone (VCFZ) is an active extensional fault cutting through carbonates in the Italian Central Apennines. The fault zone was exhumed from $\sim 2 \mathrm{~km}$ depth and accommodated a normal throw of $\sim 2 \mathrm{~km}$ since Early-Pleistocene. In the studied area, the master fault of the VCFZ dips $\mathrm{N} 210 / 54^{\circ}$ and juxtaposes Quaternary colluvial deposits in the hangingwall with cataclastic dolostones in the footwall. Detailed mapping of the fault zone rocks within the $\sim 300 \mathrm{~m}$ thick footwall-block evidenced the presence of five main structural units (Low Strain Damage Zone, High Strain Damage Zone, Breccia Unit, Cataclastic Unit 1 and Cataclastic Unit 2). The Breccia Unit results from the Pleistocene extensional reactivation of a pre-existing Pliocene thrust. The Cataclastic Unit 1 forms a $40 \mathrm{~m}$ thick band lining the master fault and recording in-situ shattering due to the propagation of multiple seismic ruptures. Seismic faulting is suggested also by the occurrence of mirror-like slip surfaces, highly localized sheared calcite-bearing veins and fluidized cataclasites. The VCFZ architecture compares well with seismological studies of the L'Aquila 2009 seismic sequence (mainshock $\mathrm{M}_{\mathrm{W}}$ 6.1), which imaged the reactivation of shallow-seated low-angle normal faults (Breccia Unit) cut by major high-angle normal faults (Cataclastic Units). 


\section{Introduction}

Thick carbonate sedimentary sequences $(4-10 \mathrm{~km})$ are common within the shallow crust of many seismically active areas worldwide, including the circum-Mediterranean mountain belts. In most of these belts (e.g., the Apennines, Italy; the Hellenides-Dinarides, Balkan Peninsula; the Maghrebides, Algeria-Tunisia) moderate to large earthquakes nucleate and propagate within carbonate host rocks (i.e., limestones and dolostones) (e.g., Di Bucci and Mazzoli, 2003; Burchfiel et al., 2008). Modern advanced geophysical and seismological techniques (e.g., tomographic studies, trapped waves, double-difference method; Waldhauser and Ellsworth, 2000; Di Stefano et al., 2011; Allam and Ben-Zion, 2012) allow to image the geometrical complexity of active buried fault zones with high spatial resolution (i.e., tens of meters) (e.g., Schaff et al., 2002; Chiaraluce et al., 2011; Valoroso et al., 2013, 2014) comparable to the resolution of geological field observations (e.g., Collettini et al., 2014). Therefore, the characterization of the internal structure of exhumed fault zones in the field is even more necessary both for the validation of the remotely acquired geophysical/seismological observations and for the investigation of the deformation processes active at smaller scale during the seismic cycle (e.g., Alvarez et al., 1978; Lavecchia, 1985; Wojtal and Mitra, 1986; Gratier and Gamond, 1990; Willemse et al., 1997; Faulkner et al., 2003; Agosta and Aydin, 2006; Mitchell and Faulkner, 2009; Bistacchi et al., 2010; Mitchell et al., 2011; Fondriest et al., 2012; Tesei et al., 2013; Bullock et al., 2014; Collettini et al., 2014). Regarding the deformation processes, clues can arise from laboratory experiments conducted both on cohesive and non-cohesive rocks (e.g., Paterson, 1958; Rutter, 1983; Verberne et al., 2010; De Paola et al., 2011; Di Toro et al., 2011; Smith et al., 2013) and from detailed microstructural investigations of both natural and experimental fault rocks through different techniques, such as cathodoluminescence (e.g., Clemenzi et al., 2015), electron back scatter diffraction (e.g., Smith et al., 2013), optical-, electron- and atomic force- microscopy (e.g., Siman-Tov et al., 2013; Tesei et al.,2013; Viti et al., 2014), water- and laser-granulometry (e.g., Billi and Storti, 2004; Storti et al., 2007;). 
Based on these studies, simplified models of fault zones have been developed to describe the

80

81

82

83

84

85

86

87

88

89

90

91

92

93

94

architecture and permeability of fault zones. In particular, they consist of a fault core, where most of the strain is accommodated, surrounded by an intensely deformed damage zone, which grades into a host rock with background deformation level (Chester and Logan, 1986; Caine et al., 1996; Shipton et al., 2006; Childs et al., 2009; Faulkner et al., 2010). The fault core is characterized by intense faulting and includes fault products like gouges, ultracataclasites, cataclasites and breccias (Sibson, 1977). The damage zone generally comprises most of the fault zone volume (up to hundreds of meters in thickness) and includes rocks that underwent fault-related fracturing, veining and subsidiary faulting, but maintain their primary features (Caine et al., 1996; Wibberley et al., 2008). Though this model describes fairly well a number of fault zones in different tectonic settings and lithologies (Faulkner et al., 2003; Wibberley and Shimamoto, 2003; Agosta and Aydin, 2006; Micarelli et al., 2006), it may result oversimplified when the presence of inherited structures developed through different times and kinematics results in complex spatial relationships between high- and low-strain compartments (e.g., Fagereng and Sibson, 2010). This point is of paramount importance in carbonates, which are frequently affected by the presence of joints, pressure solution seams, veins and faults derived from sequential deformation events (e.g., Agosta and Aydin, 2006; Aydin et al., 2010). Moreover, carbonates rocks are frequently characterized by compositional and facies heterogeneities (e.g., bedding thickness variation, laminations, grain size, presence of marl layers) that have a strong influence on rock mechanical and transport properties (Billi et al., 2003; Bonson et al., 2007; Tesei et al., 2013; Bullock et al., 2014; Michie et al., 2014; Tesei et al., 2014).

The carbonate-dominated sequences of the Apennines have experienced the alternation of extensional and compressional deformation regimes since Jurassic times, resulting in a complex structural setting on which the Quaternary extension is superposed (Elter et al., 1975). In particular, the Apennines expose the sedimentary sequences of the passive margin associated with the opening of the Alpine Tethys, subsequently involved in the westward subduction of the African plate underneath Eurasia (Boccaletti et al., 1971; Patacca et al., 1990) starting from the Eocene and the 
build-up of the collisional chain (fold-and-thrust belt) from Pliocene onwards (Malinverno and Ryan, 1986; Buiter et al., 1998; Jolivet and Faccenna, 2000; Vezzani et al., 2010; Molli and Malavieille, 2011; Carminati et al., 2012; Cardello and Doglioni, 2014;). Since late TortonianMessinian times, the eastward rollback of the subducting plate (Malinverno and Ryan, 1986) resulted in a progressive eastward migration of the fold-and-thrust belt and backarc extension started affecting the upper plate. As a consequence, the former compressional domains in the hinterland of the Apennine belt have been progressively subjected to extension coaxial with compression (Elter et al., 1975; Ghisetti and Vezzani, 1981; Patacca et al., 1990; Jolivet et al., 1998; Rosenbaum and Lister, 2004).

In the Central Apennines, the main topographic divide is located within the Gran Sasso Massif (GSM, the Corno Grande, $2912 \mathrm{~m}$ a.s.l. is the highest peak of the Apennines), which marks the eastern limit where active extension occurs (D'Agostino et al., 1998). The GSM is located at the transition between the Mesozoic Latium-Abruzzi carbonate platform and the Umbria-Marche pelagic domain (e.g. Parotto and Praturlon, 1975). The inherited paleogeography influenced both the construction of the thrust belt and the subsequent extension, leading to the formation of a complex array of non-cylindrical thrusts, folds and normal faults whose interpretation is still largely debated (D’Agostino et al., 1998; Calamita et al., 2003a; Speranza, 2003; Speranza et al., 2003; Vezzani et al., 2010; Santantonio and Carminati, 2011; Cardello and Doglioni, 2014). Indeed different authors described the same structural framework as the result of (i) out-of-sequence thrusting with the formation of duplex structures eventually cut by normal faults due to eastward migration of extensional domains (Ghisetti and Vezzani, 1991; Sani et al., 2004; Vezzani et al., 2010), (ii) postorogenic normal faulting due to gravitational collapse of the orogen (D'Agostino et al., 1998), or (iii) alternation of positive and negative stress inversions and subsequent rotation and folding of preexisting faults during the evolution of the belt (Calamita et al., 2003a; Calamita et al., 2003b; Calamita et al., 2008; Cardello and Doglioni, 2014). 
Extension in the GSM and surrounding areas occurred since late Pliocene-Early Pleistocene

and led to the formation of a series of seismically active extensional fault zones striking NW-SE, which are responsible for major earthquakes in the Central Apennines. A major recent seismic sequence that hit the area was associated with the L'Aquila earthquake $\left(M_{w}=6.1\right.$, April $6^{\text {th }} 2009$,

Chiarabba et al., 2009; Chiaraluce, 2012). There are still uncertainties whether the main shock of the seismic sequence was localized within the crystalline basement or in the overlying ultra-thick (up to $8 \mathrm{~km}$ ) carbonate succession (Chiaraluce, 2012; Speranza and Minelli, 2014), but it is certain that the mainshock rupture propagated through the carbonate sequence, and that some of the foreshocks and most aftershocks nucleated within and propagated through it (Chiaraluce, 2012). Focal mechanism solutions of the seismic events were mostly normal dip-slip, consistent with the mainshock $\left(\right.$ strike $=140^{\circ} \pm 5^{\circ}$, dip angle $=52^{\circ} \pm 5^{\circ} ;$ rake $=97^{\circ} \pm 10^{\circ} ;$ Chiaraluce, 2012), and just a few focal mechanism solutions showed strike-slip kinematics (Valoroso et al., 2013; 2014). extensional fault cutting through a dolomitized carbonate platform sequence in the GSM area, which is a segment of the Campo Imperatore Fault System (CIFS) (Vezzani et al., 2010). Field surveys were performed in the fault footwall block, which is excellently exposed due to the occurrence of a well-developed badland morphology. Several structural units were recognized within the fault zone. The mapped structural units allowed us to document the evidence for a Pliocene dolomitized thrust zone and determine its crosscutting relationships with the Quaternary extensional structures of the VCFZ. Microstructural and field observations suggest that most of the slip surfaces within the VCFZ experienced coseismic deformation. Therefore the VCFZ can be considered as an exhumed analogue of seismogenic sources active in the Central Apennines. Based on this assumption we finally compare the overall geometry and kinematics of the exposed section of the VCFZ (footwall block) with the geophysically imaged structures of the L'Aquila fault system activated during the April 2009 seismic sequence. 


\section{Geological setting}

\subsection{The Gran Sasso Massif}

The GSM is one of the principal structural features of the Central Apennines and formed during Late Messinian, Early-Middle Pliocene orogenic contraction (Ghisetti and Vezzani, 1991). The main thrust and related anticline display an arcuate geometry that consists of two main segments striking $\sim$ E-W and N-S, respectively (Fig. 1a). The E-W striking segment is characterized by an overturned anticline in the hangingwall, cut by out-of-sequence dip-slip thrusts (e.g., Ghisetti and Vezzani, 1991). The N-S striking segment shows both dip-slip and right-lateral strike-slip components (Speranza et al., 2003; Vezzani et al., 2010). The GSM consists of an array of six major thrust faults crosscutting each other in an out-of-sequence geometry (Ghisetti and Vezzani, 1991) with the uppermost thrust faults outcropping in the Vado di Corno area (i.e., the Omo Morto thrust fault; Ghisetti and Vezzani, 1991; Fig. 1b). Early Pleistocene to Present extension within the GSM is testified by the presence of a well-developed system of active extensional fault zones including the VCFZ described in this manuscript (e.g., D’Agostino et al., 1998; Galadini, 1999).

In the study area, the VCFZ is developed mostly within the same lithostratigraphic unit, namely the Calcare Massiccio Fm. (Lower Jurassic; e.g. Adamoli et al., 2012; Fig. 1b-c), which consists of an up to $600 \mathrm{~m}$ thick sequence of whitish to brownish limestones with beds $(5-50 \mathrm{~cm}$ thick) and intervals (1-5 m thick) organized in cyclothems. The ciclothems comprise grainstones, packstones and wackestones with oolites, oncolites, intraclasts, peloids and trails of birdeyes and fenestrae (Adamoli et al., 2003). The occurrence of dolostones is frequent. This is the case of the studied outcrops, which are located within a wide band (up to $300 \mathrm{~m}$ thick) of intensely deformed dolostones. Exposures of undeformed dolostones are not observed within the study area. Nevertheless, the primary sedimentary and diagenetic features of the dolostones are preserved 
Fig. 4). At least two dolostone facies were distinguished: (i) dolomicrite to dolomitic packstonewackestones with stromatolitic laminations and preserved original microfabric (i.e., allochems of limestone precursor) and (ii) crystalline dolostones with coarser average crystal/grain size, which locally are nodular and porous (fenestrae, etc.). The two facies are in stratigraphic continuity or are separated by irregular boundaries (e.g., rock lenses), and are interpreted as the product of different diagenesis (i.e., timing and intensity of dolomitization).

Other lithologies outcropping along the fault zone adjacent to the study area consist of the slope and basinal deposits of the Corniola (mudstone, Lower Jurassic), Verde Ammonitico e Calcari e Marne a Posidonia (micritic limestone, Lower-Middle Jurassic), Calcari Bioclastici Inferiori (breccias and megabreccias Middle-Upper Jurassic) and Maiolica Detritica (micritic limestone, Upper Jurassic-Lower Cretaceous) formations (Adamoli et al., 2012). The Verde Ammonitico $e$ Calcari e Marne a Posidonia Fm., hereby simply indicated as Verde Ammonitico Fm., consists of green to dark grey micrite, locally intercalated with marly layers and levels rich in dark chert. To the east of the study area, the Verde Ammonitico Fm. is overthrusted by the Calcare Massiccio Fm. (e.g., Ghisetti and Vezzani, 1991; Adamoli et al., 2012; Fig. 1b-d). In the footwall of the VCFZ, we found local occurrences of strongly dolomitized Verde Ammonitico Fm. and associated dark chert remnants, typically underlying the dolomitized Calcare Massiccio Fm. This indicates that the stacking exposed to the east, actually occurs also in the footwall of the VCFZ, in the study area, where both units underwent severe dolomitization preceding Quaternary extensional faulting. Small outcrops of the Maiolica Detritica Fm. occur in the hangingwall of the fault zone near Mt. Brancastello (Fig. 1d).

The Campo Imperatore intramontane basin, in the hanging wall of the VCFZ, is characterized by glacial, alluvial and colluvial deposits. The former are related to Late Pleistocene glacial events (Giraudi and Frezzotti, 1995, 1997; Adamoli et al., 2012); the latter are Holocene in age and derived from weathering of the exposed carbonate rocks. These loose deposits feed well- 
developed alluvial fan systems (Adamoli et al., 2012 and references therein). In this study all these

207 deposits will be comprehensively referred to as Quaternary deposits.

208

\subsection{The Vado di Corno Fault Zone}

The VCFZ outcrops continuously for ca. $5 \mathrm{~km}$ bordering the northern part of the Campo Imperatore intramontane basin (Fig. 1b). The VCFZ belongs to a larger fault system (the so called Campo Imperatore Fault System - CIFS) which runs for $\sim 20 \mathrm{~km}$ in the Gran Sasso Massif and is thought to have accommodated a cumulative throw of 2000-3000 m (Ghisetti and Vezzani, 1991; D’Agostino et al., 1998; Ghisetti and Vezzani, 1999). The exposed fault zone was exhumed from ca. 1-2 km depth starting from Early-Pleistocene (Agosta and Kirschner, 2003).

Between Vado di Corno and Mt. Brancastello, the VCFZ outcrops almost continuously along about 20 sub-parallel creeks oriented orthogonal to the average strike of the fault zone. The creeks are affected to fast erosion and the resulting badland topography offers a unique threedimensional view into the fault zone footwall block. With the aim of describing the internal structure of the VCFZ, we performed a detailed survey along the strike of the fault zone and selected a creek (UTM coordinates, zone 33N WGS84, 385611 E, 4700440 N, white arrow in Fig. 1b) that provided a representative cross-section of the fault. Measurements of bedding surfaces (dip azimuth/dip angle $\mathrm{N} 270 / 20^{\circ}$, Fig. 1e) in the fault zone show a gently W-dipping monocline at the hangingwall block of the GSM thrust.

The seismic activity of the CIFS is documented both by paleoseismological studies and instrumental seismicity (Giraudi and Frezzotti, 1995; Galli et al., 2002; Galadini et al., 2003; ISIDe Working Group, 2010). Trenches dug in the Campo Imperatore basin highlighted at least three main surface ruptures since Late Pleistocene; an earthquake with magnitude up to $M_{w}=6.95$ was estimated to be produced in case of activation of the entire extensional Campo Imperatore Fault System (Galli et al., 2002; Galadini et al., 2003). Current seismicity is documented in the GSM; in 
particular, the CIFS is characterized by relatively continuous microseismicity with $\mathrm{M}_{\mathrm{L}}<2.5$ (ISIDe

231 Working Group, 2010).

\section{Methods}

The footwall block of the VCFZ was mapped at 1:500 scale in a selected creek and the adjacent areas (mapped area c. $0.2 \times 0.4 \mathrm{~km}^{2}$; Fig. 2a) using, as a topographic basis, orthorectified aerial photographs (spatial resolution $0.2 \mathrm{~m}$, courtesy of the Regione Abruzzo: www.regione.abruzzo.it/xcartografia). The resulting structural map of the exposed fault zone is shown in Fig. 2a. The map shows (i) the principal fault strands and (ii) the spatial distribution of fault zone structural units, i.e. rock volumes affected by distinct bulk deformation intensity and, likely, deformation processes. Fault zone structural units were defined on the base of a series of mesoscale observations such as:

Strain Damage Zone (LSDZ), (ii) the High Strain Damage Zone (HSDZ), (iii) the Breccia Unit

damage zone. These data were digitized using ArcGIS@ $\odot$ and Move@ $\subseteq$ software.

Structural data, such as attitude of bedding, joints, and veins, orientation and kinematics of faults, and fracture frequency in damage zones, were collected at sites evenly distributed across the 
outcrops and located using a handheld GPS (accuracy typically $\pm 2 \mathrm{~m}$ ) and along scan-lines oriented perpendicular to the master fault.

Fracture abundance (i.e., areal fracture density and intensity, $\mathrm{P}_{20}$ and $\mathrm{P}_{21}$ respectively, sensu

Dershowitz and Herda, 1992) was computed in both the LSDZ and the HSDZ to quantify faultrelated damage at increasing distance from the master fault of the VCFZ. The areal fracture density $\left(\mathrm{P}_{20}\right)$ is defined as number of trace centers per unit sampling area $\left[\mathrm{m}^{-2}\right]$, while the areal fracture intensity $\left(\mathrm{P}_{21}\right)$ is defined as length of fracture traces per unit sampling area $\left[\mathrm{m}^{-1}\right]$. Since both $\mathrm{P}_{20}$ and $\mathrm{P}_{21}$ are orientation-dependent, they were measured perpendicular to the principal fracture/fault systems of the structural domain. To prevent bias due to the resolution of the techniques (i.e., data truncation) and the finite size of the sampled domain (i.e., data censoring), measurements were performed on a selected range of fracture length. The upper and lower cutoff were specifically chosen to consider only the linear interval of the trace length distribution in a logarithmic plot (i.e., 0.407-1.125 $\mathrm{m}$ and $0.01-0.1 \mathrm{~m}$ for the LSDZ and HSDZ respectively). Truncation and censoring take place since the lower cutoff usually exceeds the resolution of the images (typically $\leq 1 \mathrm{~cm}$ ) and the upper cutoff is smaller than the dimension of the sampled domain. Since the selected range for computing fracture abundance was limited up to two orders of magnitude, we used this data only for comparison between the damage intensity in the LSDZ and HSDZ. For the LSDZ, fracture traces were digitized in Move $(\subset)$ on a vertical section oriented perpendicular to the master fault (strike $\mathrm{N} 30^{\circ}$ ) obtained from a georeferenced photogrammetric model. Traces were then exported in GoCADC to compute trace properties (centroid distance from the master fault, trace length, trend and plunge). Finally, fracture statistics were computed with an ad-hoc Matlab@ script. For the HSDZ, traces were mapped in ArcGISC on smaller image frames oriented both parallel and perpendicular to the master fault (window sampling dimension $60 \mathrm{x} 40 \mathrm{~cm}$, photo resolution $<1$ $\mathrm{mm})$. Fracture statistics were then calculated using the same Matlab@ script as for the LSDZ. 
slipping zones. Microstructural observations were conducted on polished thin sections $(n=40)$ cut

perpendicular to the veins and the slip surfaces and oriented either parallel or perpendicular to fault lineations, using transmitted-light optical microscopy (OM), field emission scanning electron microscopy (FE-SEM), and optical microscopy cathodoluminescence (OM-CL). Mineral phase identification and elemental analysis were performed through energy dispersive spectroscopy (EDS) at the FE-SEM, while bulk mineralogy was derived from X-ray powder diffraction (XRPD) analyses. Analyses were conducted at the Department of Geoscience in Padua (Italy) and at HT-HP laboratories at the Istituto Nazionale di Geofisica e Vulcanologia (INGV) in Rome (Italy).

\section{Cross-sectional structural architecture}

The VCFZ in the mapped creek consists of an array of NW-SE striking, mostly SW dipping, fault surfaces. The major ones can be easily followed in the field for distances of 20-30 m and are characterized by strong shear strain localization within layers of cataclasite with thickness up to $30 \mathrm{~cm}$. They bound different structural units both in the fault core and in the damage zone (Fig. 2a-b). At the base of the badlands, the contact between the cataclastic rocks and the hangingwall Quaternary deposits is marked by a polished fault slip surface with average dip azimuth/dip of $\mathrm{N} 209 / 54^{\circ}$ and average pitch of $80^{\circ}$ to the $\mathrm{E}$ (Fig. 3a). The fault is assumed to be the master fault because (i) it marks the major discontinuity between the Quaternary alluvial deposits of the Campo Imperatore intramontane basin in the hangingwall block and the Jurassic carbonates in the footwall block (Fig. 3b) and, (ii) it is associated with a $~ 40$ m thick cataclastic fault core (CU1) in the footwall block. The master fault principal slip zone consists of a $\sim 20 \mathrm{~cm}$ thick cataclastic layer with mixed hangingwall and footwall materials, characterized by up to two-centimeter-thick, ultracataclasites are wavy and resemble fluidization features (e.g., Brodsky et al., 2009). Moreover, they are truncated by sharp slip surfaces (Fig. 3c) (e.g., Siman-Tov et al., 2013). 
A representative cross-section of the VCFZ footwall is provided in figure $2 \mathrm{~b}$. The CU1 lines the master fault forming a continuous $\sim 40 \mathrm{~m}$ thick band. Moving to the NE, the CU1 grades into the $\mathrm{CU} 2$, which crosscuts the BU along a SW dipping major synthetic normal fault. The BU is the lowermost structural unit, which outcrops along the bottom of the creek, with the mean attitude of a gently SW dipping flat (Fig. 2a). The BU is embedded within the damage zone units (LSDZ and HSDZ) (Fig. 2a-b), which show a sharp fault contact with the cataclastic rocks (CU1 and CU2).

Most of the damage zone volume consists of HSDZ, while the LSDZ represents a ca. $20 \mathrm{~m}$ thick isolated block (in direction orthogonal to the Vado di Corno master fault) embedded within the HSDZ. Bands of cataclastic rocks (mostly CU1) up to few meters thick were also documented the master fault. Smaller volumes of LSDZ occur also in the northernmost outer portion of the creek towards the mountain ridge.

The faults in the footwall damage zone typically show high dip angles $\left(>70^{\circ}\right)$ and are organized in two main sets synthetic and antithetic with respect to the master fault. A third set striking NE-SW is also present (Fig. 3d). Synthetic faults include two subsets with attitude (dip azimuth/dip angle) $\mathrm{N} 195 / 75^{\circ}$ and $\mathrm{N} 225 / 80^{\circ}$, while the average orientation of antithetic faults is $\mathrm{N} 50 / 85^{\circ}$. NE-SW striking faults control the topography in the upper part of the creek (usually at distance greater than $100 \mathrm{~m}$ from the master fault) and dip both towards SE and NW. Grooves and fault lineations are generally dip-slip for synthetic faults, while antithetic- and NE-SW striking faults exhibit both dip-slip and left- (rarely right-) lateral slip kinematics. The absence of clear around the orientations of the faults (Fig. 3d). markers makes difficult to estimate the amount of offset accommodated by individual faults. Poles to joints (opening mode fractures) are at high angle and show different orientations with clustering 
The Low Strain Damage Zone (LSDZ) consists of relatively poorly deformed rock volumes, where sedimentary features of the host rocks such as bedding surfaces, stromatolitic lamination, planar trails of fenestrae and "burial" stylolites/pressure solution seams are well recognizable (Fig. 4a-b). In the selected creek, the LSDZ outcrops as a ca. $20 \mathrm{~m}$ thick block (measured orthogonal to the master fault, Fig. 2a). Smaller volumes of LSDZ, less than $15 \mathrm{~m}$ thick, are found in the upper part of the mountain ridge (i.e., upper right part in Fig. 2a). Faults within LSDZ are spaced 1 to 15 $\mathrm{m}$ apart and dislocate strata with normal separation (i.e., displacement) $<1 \mathrm{~m}$. Joints are the most abundant deformation features, with minor strata-bound calcite and dolomite veins, and subsidiary faults (Fig. 4a-b). Since most faults and fractures in this area are synthetic and antithetic to the master fault (Fig. 4c), areal fracture density and intensity were calculated on a continuously exposed outcrop oriented at high angle to the master fault that have been projected in Move $\subset$ on a vertical cross section perpendicular to the master fault (Fig. 4d). Fracture abundance was computed for fracture traces with length in the range $0.407-1.125 \mathrm{~m}$ and resulted in $\mathrm{P}_{20}=3.3 \mathrm{~m}^{-2}$ and $\mathrm{P}_{21}=$ up to $0.2 \mathrm{~mm}$ for calcite and $2-3 \mathrm{~mm}$ for dolomite veins. Calcite veins have a lateral continuity typically $<10 \mathrm{~cm}$, while dolomite veins have lateral continuity usually $10-15 \mathrm{~cm}$ and are spaced up to few centimeters apart. Systematic cross-cutting relationships suggest that calcite-filled veins are younger than the dolomite-filled ones (Fig. 4e).

\subsection{High Strain Damage Zone}

The High Strain Damage Zone (HSDZ) consists of fractured rock volumes with significantly higher fracture density/intensity with respect to the LSDZ. The HSDZ is the structural unit that occupies the largest volume within the VCFZ (thickness of 150 - 300 m measured orthogonal to the master fault). Faults are few and spaced 5-15 m apart. Fracturing is pervasive and typically results 
(Fig. 5b). In this structural unit, fracture attitude is scattered and is associated to synthetic, antithetic and NE-SW striking faults (Fig. 5a). Veins are less frequent. Here, the higher fracture intensity makes the recognition of primary sedimentary features much more difficult compared to LSDZ.

Quantitative scan-areas were performed on image frames oriented both parallel and perpendicular

to the master fault (frame attitudes were $\mathrm{N} 204 / 74^{\circ}$ and $\mathrm{N} 292 / 66^{\circ}$, respectively). For sampling windows oriented perpendicular to the master fault, $\mathrm{P}_{20}=5170 \mathrm{~m}^{-2}$ and $\mathrm{P}_{21}=124.454 \mathrm{~m}^{-1}$ (fracture trace length range $0.01-0.1 \mathrm{~m}$, Fig. 5c). For sampling windows oriented parallel to the master fault, $P_{20}=5107 \mathrm{~m}^{-2}$ and $\mathrm{P}_{21}=118.377 \mathrm{~m}^{-1}$ (fracture trace length range $0.01-0.1 \mathrm{~m}$, Fig. $5 \mathrm{~d}$ ).

\subsection{Breccia Unit}

The BU consists of rocks that show evidence of pervasive secondary dolomitization of the host rock and dolomite veining. This structural unit is strictly related to areas where the Verde Ammonitico Fm. is exposed and at the outcrop scale it mainly consists of grey, green to brownish in color fault rocks (Fig. 6a), which can be classified mostly as cohesive crush breccias (Sibson, 1977). Following the classification proposed by Mort and Woodcock (2008) the breccias should furthermore be classified as "mosaic-crackle breccias" (i.e., clast concentration > 60\%, clast rotation $<20 \%$ ). The BU typically outcrops (i) at the bottom of the creeks, (ii) associated with NNE-SSW striking low-angle (dip angle $20-40^{\circ}$ ) oblique faults with contractional S-C cleavages and R-shear fractures (Riedel fractures) or (iii) related with low-angle normal faults characterized by an older-on-younger "stratigraphy" (Fig. 6b-c). The transition to the less deformed structural units of the damage zones is typically gradational, i.e. characterized by progressively decreasing vein intensity, while the transition to the cataclastic rock is generally sharp and fault-bounded (e.g., Fig. 6b). Faults inside the BU are few and have polished to mirror-like slip surfaces associated with very localized cataclastic to ultracataclastic brownish slipping zones with thickness up to 5-10 $\mathrm{cm}$. Major faults (i.e., fault that can be followed in the field for more than $10 \mathrm{~m}$ ) within the BU are usually lined by $<50 \mathrm{~cm}$ thick fault cores. 
Dolomite veins in less brecciated areas have large lateral continuity (up to few meters), planar geometries and large aperture (2-3 $\mathrm{cm}$ at maximum, 5-6 $\mathrm{mm}$ on average). They are typically found in conjugate sets dipping perpendicular (NW-SE and NE-SW striking with dip angle $75-85^{\circ}$ ) and parallel to low-angle bedding surfaces (Fig. 6d-e); however, when approaching subsidiary faults, veins are arranged in chaotic networks that overprint tectonic brecciation. Breccia clasts (up to tens of centimeters in size) are generally angular but locally show irregular cuspate-lobate boundaries related to a diffuse presence of dolomite veins (Fig. 6f).

\subsection{Cataclastic Units}

The cataclastic structural units include mainly fault rocks of the "cataclasite series" according to the definition by Sibson (1977) (i.e., volumetric matrix content of 10-50\% for a protocataclasite, $50-90 \%$ for a cataclasite and $90-100 \%$ for an ultracataclasite); therefore we called it "cataclastic unit" (CU). At the outcrop scale, depending of the grade of cataclasis and preservation of the protolith, two subunits of the CU, called cataclastic unit 1 (CU1) and cataclastic unit 2 (CU2) respectively, were identified. The contact between CU1 and CU2 can be both sharp 400 (i.e., marked by faults) or transitional (i.e., gradual change in fabric from CU1 to CU2). In the latter 401 case, the contact between the CU1 and CU2 is usually mapped where one subunit becomes 402 dominant in terms of volume with respect to the other one.

\subsubsection{Cataclastic Unit 2}

The CU2 comprises brownish proto-cataclasites and cataclasites where the original fabric of the protolith is still recognizable (Fig. 7a). Clasts ( $\mathrm{cm}$ - to tens of $\mathrm{cm}$ in size) are pervasively 407 fractured in-situ down to the millimeter scale (in-situ shattering sensu Brune, 2001). At the outcrop scale, the CU2 exhibits great variability in the fabric depending on the source rock (e.g. Calcare Massiccio rather than Verde Ammonitico). In particular, the occurrence of heterogeneities in the protolith, such as the alternation of facies in the Calcare Massiccio Fm. or chert nodules in the 
411 Verde Ammonitico Fm., typically result in a lower intensity of deformation of these features and

412 their preservation within the CU2.

At the outcrop scale, the CU2 is cut by a relatively dense network of dolomite- and calcite-

414 bearing veins and veinlets (maximum aperture $1 \mathrm{~cm}$ ), which contribute to seal the entire fragmented 415 rock volume (Fig. 7b). Most of the veins have scarce lateral continuity (up to few $10 \mathrm{~s} \mathrm{~cm}$ for 416 dolomite veins and $<10 \mathrm{~cm}$ for calcite veins) and irregular shape possibly due to subsequent 417 shearing/rotation and complex cross-cutting/abutting relationships among the different sets of veins 418 and faults. Their attitude distribution is scattered though veins have often high dip angles (i.e., > $41970^{\circ}$, Fig. 7c). Pockets of "microbreccias" (clasts size less $<1 \mathrm{~mm}$ ) are observed within the CU2 as 420 consequence of the complex intersection of branching of larger veins (Fig. 7d). The "microbreccia" 421 clasts are typically separated by microcrystalline calcite-filled veins (crystal size 5-10 $\mu \mathrm{m}$ ) and 422 often seem to be not in contact.

\subsubsection{Cataclastic Unit 1}

The CU1 consists of a white in color, fine-grained (average grain size $<1-2 \mathrm{~mm}$ ) and calcite cemented ultracataclasite (Fig. 8a). Well-rounded "survivor" clasts in the cataclasite are few and usually small in size (usually $<1-2 \mathrm{~cm}$ ). Locally, the CU1 includes lithons of the CU2 up to tens of meters in size (Fig. 8b), which are bounded or cross-cut by minor faults, or are in contact with the surrounding cataclasite through irregular wavy contacts.

At the microscale, calcite veins have sharp boundaries, are arranged in en-echelon or branching arrays and are often cross-cut and displaced by shear fractures with an offset typically < $1 \mathrm{~mm}$ (Fig. 8c). Small calcite veins with fuzzy boundaries, irregular geometries and lateral continuity of few millimeters are also frequent. Veins are filled by blocky calcite crystals with average size of 10-50 $\mu \mathrm{m}$. The CU1 typically contains polished (i.e., mirror-like) slip surfaces (Fig. 8d) associated with cataclastic and ultracataclastic bands with foliated and non-foliated fabric (see section 6 for an extensive description of the slipping zones). The mirror-like slip surfaces sharply 
truncate dolostone and small calcite clasts (grain size $<10 \mu \mathrm{m}$ ) (Fig. 8d) and are often decorated by iron oxides and hydroxides. Fault spacing is usually less than $10 \mathrm{~cm}$. In places, $\mathrm{mm}$ - to $\mathrm{cm}$ thick deformation bands (i.e., narrow tabular structures with limited shear offset, Fossen et al., 2007) were found in the granular cataclastic unit (Fig. 8e).

\section{Microstructures of the slipping zones}

The five structural units of the VCFZ are cut by faults with different types of slipping zones including: (1) highly localized sheared calcite veins, (2) non-foliated cataclasites to ultracataclasites, (3) foliated ultracataclasites with flow structures, and 4) deformation bands. 447 Slipping zones (1), (2) and (3) are often bounded by mirror-like principal slip surfaces. Here we 448 define the slip surface as the fault surface itself, sometimes containing slip direction indicators such 449 as slickenlines and surface grooves (Smith et al., 2011). The slipping zone, up to several 450 centimeters thick, develops beneath the slip surface and consists of variously developed fault rocks 451 described following the classification of Sibson (1977). Together, the slip surface and the slipping 452 zone are thought to accommodate the bulk of displacement during seismic faulting (Sibson, 2003). 453 In addition, we define the principal slip surface (PSS) as the slip surface on which the majority of 454 the displacement is thought to be accommodated.

\subsection{Highly localized sheared calcite veins}

Locally within the CU1 shear deformation is accommodated within up to $200 \mu \mathrm{m}$ thick slipping zones exploiting preexisting calcite veins. The latter are up to $300-500 \mu \mathrm{m}$ thick and sealed by undeformed polygonal calcite crystals with an average size of ca. 50-100 $\mu \mathrm{m}$ (Fig. 9a). Instead, slipping zones contain fine-grained calcite crystals $50 \mathrm{~nm}$ to $1 \mu \mathrm{m}$ in size rimming sub-angular to rounded micrometer in size dolomite grains (Fig. 9b). The calcite grains are often euhedral and with 
texture, Fig. 9c). The sheared calcite veins are cut by sharp, ultra-smooth slip surfaces truncating

464 larger dolostone grains $(>100 \mu \mathrm{m}$ in size) (Fig. 9d). The sheared veins record multiple cycles of fracture opening - calcite deposition - shearing, as suggested by the occurrence, within the same slipping zone, of multiple slip surfaces and deformed veins (Fig. 9e). Both undeformed veins and sheared veins sub-parallel and at high angle to the principal slip surface are observed, with the high angle sheared veins frequently dislocating the subparallel ones (Fig. 9a-e).

\subsection{Non-foliated cataclasites}

Most slipping zones of the CU1 and CU2 - and few of the BU - are $5 \mathrm{~cm}$ to $30 \mathrm{~cm}$ thick and consist of dolomite-built cataclasites grading into ultracataclasites (Sibson, 1977) (Fig. 10a). The non-foliated cataclasites consist of angular to sub-rounded dolostone clasts (size $<1 \mathrm{~cm}$ ) immersed in a matrix of sub-angular dolostones grains (size below $50 \mu \mathrm{m}$ down to $1 \mu \mathrm{m}$ ). Extended areas and bands of calcite cement with $10-20 \mu \mathrm{m}$ in size polygonal crystals occur locally as infilling of pores in the dolomite matrix (Fig. 10b). Moving towards the principal slip surface, the volume of matrix increases and the cataclasite grades into ultracataclasites. Both cataclasites and ultracataclasites contain reworked clasts derived from fragments of older slipping zones or from the fragmentation of the calcite cement. Both synthetic and antithetic Riedel shear fractures and stylolites are occasionally found within the ultracataclasites.

Some of the cataclasites include up to $1 \mathrm{~cm}$ in size radially fragmented dolostone clasts immersed in a matrix made of angular dolostone clasts with evidence of splitting down to the micrometer scale (Fig. 10c-d). These fault rocks lack clear evidence of shear strain accommodation and are interpreted as the result of in-situ shattering (Fondriest et al., 2015; Schröckenfuchs et al., 2015). Minor faults cutting the LSDZ and HSDZ are usually associated with slipping zones with a proto-cataclastic fabric (volumetric matrix content $<20 \%$ ). Most of the slipping zones described above and in particular those associated to cataclasites, ultracataclasites and in-situ shattered fault 
clasts (Fig. 10e).

\subsection{Foliated cataclasites}

Some of the dolomite-rich cataclasites with the highest content (>30\% in volume) of

calcite as cement-rich areas or bands display a peculiar "foliated" fabric. These "foliated cataclasites" consist of bands of fragmented dolomite clasts (grey in BSE-SEM images) alternating with either patchy or more continuous layers of sheared calcite matrix (white in BSE-SEM images) (Fig. 11a). The calcite layers contain clasts from few to hundreds of micrometers in size arranged in a S- or C-type foliation consistent with the shear sense of the slipping zone (Fig. 11a). Elongated "tails" of fine-grained dolomite and calcite matrix (down to few micrometers in size) wrap larger dolomite and calcite clasts. Similar microstructures have been documented by Smith et al. (2016) in rotary shear experiments performed at seismic slip velocity in mixed calcite/dolomite gouges and resemble porphyroclastic systems in mylonites (e.g., Passchier and Trouw, 2005) or rigid grains suspended in foliated clay-rich fault gouges (Cladouhos, 1999). The foliated calcite-rich matrix is microstructurally similar to the one found in sheared calcite veins (see Fig. $11 \mathrm{~b}$ and $8 \mathrm{c}$ ).

Foliated cataclasites and ultracataclasites made of dolomite/calcite mixtures are frequent within the CU1 and CU2 and decorate the faults marking the contact between the two structural units. Moreover, the pluri-centimeter thick slipping zone associated with the master fault and bordering the Quaternary deposits consists of reddish and whitish foliated ultracataclasites (Fig. 3c). Here, ultracataclasites consist of dolomite and calcite (reddish in color ultracataclasite) or dolomite (whitish ultracataclasite) clasts $<200 \mu \mathrm{m}$ in size immersed in an ultra-fine grained $(<1 \mu \mathrm{m})$ foliated 510 dolomite matrix with calcite cement (Fig. 11c). Rounded clasts of microcrystalline chert (up to

511 hundreds of micrometer in size) and fine-grained iron oxides suggest mixing of quaternary-derived material within the slipping zone. 
irregular cuspate-lobate boundaries (Fig. 11c), and (ii) injection veins filled with micrometric calcite crystals or cement-supported ultracataclasites (Fig. 11d), is widespread in the slipping zones lining the master fault and also within some of the foliated cataclasites of the CU and BU. In addition, many of the dolomite-calcite foliated cataclasites and ultracataclasites are cut by mirrorlike surfaces with truncated grains.

\subsection{Deformation bands}

Few-millimeters-thick deformation bands are observed to cut through the CU1 in areas where the cataclasites appear less cemented or even loose (Fig. 8e). These granular bands are found in the footwall within a maximum distance of 10-20 m from the master fault. According to Fossen et al. (2007), these features can be classified as cataclastic bands since they cut through relatively high porosity cataclastic material and are characterized by a less porous core, which has undergone grain size reduction by cataclasis and pore-space collapse. The cataclastic bands are up to 2-3 mm thick, consist of fine-grained comminuted dolomite (average grain size $<10 \mu \mathrm{m}$ ) with some larger dolomite clasts up to $300-500 \mu \mathrm{m}$ in size and very rare calcite cement (Fig. 11e-f). The latter occurs in areas with crystals that are usually $10-20 \mu \mathrm{m}$ in size. The core of the cataclastic bands is typically 200-400 $\mu \mathrm{m}$ thick and exhibits a grain-size reduction that goes down to less than $1 \mu \mathrm{m}$ (Fig. 11f).

Clasts with size $>10 \mu \mathrm{m}$ often have an angular shape, with fracturing occurring along cleavage surfaces; conversely, clasts $<5 \mu \mathrm{m}$ in size are rounded and may form intra-clast bridges. Due to lack of structural markers in the walls, offset cannot be calculated, though it is likely that cataclastic bands accommodated some shear strain other than only compaction.

\section{Discussion}

\subsection{Structural complexity of the VCFZ}


The spatial distribution of the mapped structural units and the orientation of joints and

540 subsidiary faults in the damage zone, support their genetic link with the activity of the VCFZ (e.g.,

541 Destro, 1995; Bai and Pollard, 2000). The occurrence of the LSDZ as an isolated fault bounded

542 block adjacent to the fault core is interpreted as the expression of differences in the protolith (bed

543 thickness, grain size, presence of fenestrae, etc.), which have resulted in a minor overall

544 deformation. However, the limited three-dimensional exposure of this block in the field inhibits a

545 more comprehensive understanding of the spatial relationship with the surrounding structural units.

546 The strike-slip kinematics of NE-SW striking high-angle faults in the upper part of the creek are

547 interpreted as tear faults likely accommodating lateral variations in displacement within the VCFZ.

548 The occurrence and geometry of secondary dolostones and related veins (i.e., BU), developed in the

549 Calcare Massiccio and Verde Ammonitico formations raises the question whether this major

550 dolomitization pulse was triggered by thrusting or Quaternary extension. The evidence that

551 secondary dolostone pervasively occurs along a shallow-dipping zone involving both protolith

552 lithologies implies that dolomitization exploited the thrust damage zones, thus being synchronous to

553 or postdating the contractional event responsible for the tectonic juxtaposition of the Calcare

554 Massiccio onto the Verde Ammonitico, well preserved to the East (Fig. 1b). On the other hand,

555 secondary dolostones are systematically crushed within fault rocks of the CU1, unequivocally

556 associated with the Quaternary master fault, indicating that dolomitization preceded extensional

557 faulting. Moreover, cataclasites are cemented by calcite veins. The latter have also been involved in

558 the deformation, thus providing another indirect evidence for the different environmental conditions

559 during extension. It follows that the relative timing of the major dolomitization pulse can be

560 constrained as syn- to post-thrusting in the area, but still in the contractional tectonic regime

561 (Middle to Late Pliocene). A detailed study of the evolution of dolomitization is out of our purposes

562 in this work and is the subject of specific ongoing research.

563 In the study area, the presence of the thrust did not affect the extensional fault geometry,

564 which cuts through the pre-existing structural fabric, but the related dolomitization is inferred to 
have influenced both the width of the footwall damage zone and the frequency and density of fracturing within the high- and low-strain structural units.

\subsubsection{Origin of the $C U$}

Field and microstructural observations, including fragmentation in the cataclasites locally showing lack of shearing, suggest that in-situ shattering (equivalent to rock pulverization in crystalline lithologies), played a major role in the early stages of formation of the CUs. Pulverized fault rocks are rock volumes that appear to have been shattered in-situ; they typically have very fine grain size (i.e., $<1 \mathrm{~mm}$ ) and lack of evidence of significant shearing. In-situ shattering has been already reported both in crystalline (Brune, 2001; Dor et al., 2006a, 2006b; Mitchell et al., 2011) and carbonate fault zone rocks (Agosta and Aydin, 2006; Fondriest et al., 2015; Schröckenfuchs et al., 2015).

Both theoretical and experimental investigations (e.g., Ben-Zion and Shi, 2005; Dor et al., 2006a, 2006b; Doan and Gary, 2009; Yuan et al., 2011) suggest a coseismic origin for pulverized rocks, and interpret rock pulverization as a consequence of high strain rate dynamic loading associated with the propagation of single or multiple earthquake ruptures along faults with different geometries and kinematics. More recently Doan and d'Hour (2012) and Aben et al. (2016) demonstrated that multiple milder dynamic loadings can lead to the development of pulverization bands up to hundreds of meters thick without invoking the large scale propagation of supershear rupture fronts, which are generally infrequent rupture modes (i.e, reported for straight and long boundary faults; e.g., Bouchon et al. 2003). In the VCFZ the CU1 forms a continuous band almost $40 \mathrm{~m}$ thick lining the master fault and is characterized by a rather homogeneous cataclastic fabric with a very fine grain size $(<1-2 \mathrm{~mm})$. Minor faults within the CU1 are associated with thin ultracataclastic layers that cross-cut each other but do not affect the entire cataclastic rock volume. Small rock volumes (few meters at maximum) affected by intense fracturing but lacking significant shear deformation are embedded within the CU1 (Fig. 8f-g). Moreover, looking at the microscale 
within the cataclastic rocks, exploded clasts and relics of older in-situ shattered microstructures

592 were often observed. This suggests that the propagation of multiple seismic ruptures (see section 593 7.2) might have produced in-situ shattering up to several meters from the master fault (Fig. 12a-d).

594 During each shattering event, coseismic strain localization along multiple slip surfaces evenly 595 distributed in the fractured rock mass was likely to be activated (Ma and Andrews, 2013; Fondriest 596 et al., 2015). Further displacement and strain (i.e., widening of the single cataclastic bands) were 597 then accumulated during post-seismic and interseismic stages (Fig. 12c-d). Therefore the occurrence of multiple shattering episodes which produced thick bands of intensely fragmented rocks, subsequently affected by shear strain localization, can explain the development of a $40 \mathrm{~m}$ thick homogeneous CU1 which would be difficult to develop only by catclasis.

\subsection{Evidence of coseismic slip}

Field and microstructural observations of faults and fault zone rocks suggest the propagation of seismic ruptures within the VCFZ. Faults are typically characterized by the presence of polished (i.e. mirror-like) slip surfaces associated with ultracataclastic and cataclastic slipping zones. Mirrorlike slip surfaces are common in faults cutting carbonates (Fondriest et al., 2012; Siman-Tov et al., 2013; Tesei et al., 2013) and are described as naturally polished fault surfaces with high visiblelight reflectivity, which implies an extreme smoothness at the microscale, below the wavelength of visible light (e.g., Siman-Tov et al., 2013). Recent experimental studies on both dolomite and calcite gouges and solid rocks (Fondriest et al., 2013; Smith et al., 2013; Siman-Tov et al., 2015; 611 Smith et al., 2015) show that mirror-like slip surfaces form at seismic slip rate $(\sim 0.1-1 \mathrm{~m} / \mathrm{s})$ and are associated with strong dynamic weakening and shear strain localization. Conversely to mirror-like surfaces formed at sub-seismic slip rates $(\sim 10 \mu \mathrm{m} / \mathrm{s})$ in calcite gouges (Verberne et al., 2013), mirror-like surfaces produced at seismic slip rates $(\sim 1 \mathrm{~m} / \mathrm{s})$ sharply truncate large grains (hundreds of micrometers in size) and cover most of the experimental fault surface (Fondriest et al., 2013; 
truncating mm- to $\mathrm{cm}$-in size grains (e.g., Figs. 8d; 9e) is a potential indicator of seismic rupture propagation.

A further possible evidence of seismic slip along the studied faults is the presence of submicrometric calcite euhedral grains organized in a foam texture in the sheared calcite veins (Figs. 8c; 10b). Similar microstructures were produced in experiments simulating seismic slip in calcite and dolomite gouges (De Paola et al., 2011; Fondriest et al., 2013; Smith et al., 2013; De Paola et al., 2015; Green et al., 2015; Mitchell et al., 2015; Smith et al., 2015). These foam-like textures were associated with grain-size dependent (grain boundary sliding aided by diffusion creep) fault weakening mechanisms activated during seismic slip (De Paola et al., 2015), possibly followed by sintering processes occurring at the end of seismic slip (Di Toro et al., 2015; Green et al., 2015). Moreover, these microstructures were found to be spatially related to both sheared and undeformed calcite veins sub-parallel to fine-grained ultracataclastic principal slip zones. This and the above observations are in good agreement with microstructures from other carbonate-bearing faults, in which a close association of mirror-like slip surfaces, ultracataclasites, principal slip zone veins and fluidized cataclasites was also observed (e.g., Tesei et al., 2013). The sequential opening and shearing of veins sub-parallel to localized slipping zones suggest the cyclic build-up of fluid overpressure during deformation through a fault-valve mechanism, which is thought to be associated with seismic slip events (Sibson, 1981; 1990).

The cataclastic units and the slipping zones therein include exploded clasts up to $1-2 \mathrm{~cm}$ in size with radial fractures embedded in a micrometric in size matrix composed of angular clasts with no evidence of shearing (Figs. 9c-d). This occurrence within dolostones has been already reported by Fondriest et al. (2015) and interpreted as the result of in-situ shattering due to the propagation of seismic ruptures along neighbor faults. In the VCFZ these features are typically associated with mirror-like slip surface suggesting a related seismic origin. cataclasites to coseismic sliding has been recently investigated by Smith et al. (2016) by performing 
high-velocity (imposed slip rate $\mathrm{V}<1.13 \mathrm{~m} / \mathrm{s}$ ) shear experiments on mixtures of calcite-dolomite

644 gouges. Their results show that a well-organized foliation can develop quickly from an initial random distribution as displacement is distributed along a shear band before dynamic weakening occurs. When the latter takes place, deformation is localized to a discrete slip surface, which cuts sharply the foliated gouge and accommodates most of the strain. The described microstructures exhibit striking similarities with the foliated cataclasites documented in the VCFZ (Fig. 11a) suggesting a common seismic origin.

A feature that has been documented both at the meso- and microscale related to the master fault and some foliated cataclasites within the VCFZ is the presence of "fluidization textures". These fluidized layers develop up to $5 \mathrm{~cm}$ away from the slip surface and include wavy borders and injection of material in the surrounding cataclasite (e.g., Fig. 11c). In the Kodiak accretionary complex (Alaska, USA), Brodsky et al. (2009) described cuspate-lobate, locally intrusive, contacts between black in color aphanitic rocks with flame-like and laminar to convolute flow structures interpreted as pseudotachylytes and foliated illite-rich cataclasites. Similar fluidal structures were described in slipping zones cutting carbonates and were tentatively associated with seismic faulting (Smith et al., 2011; Fondriest et al., 2012; Rowe et al., 2012). The formation of fault rocks with intrusive geometry (e.g., pinch out terminations) and laminar- to turbulent-like flow structures plus, in some cases, cuspate-lobate contacts with the wall rocks, is thought to be the result of fluidization of the slipping zone material. Triggering mechanisms may be thermal decomposition (e.g., Collettini et al., 2013), pressurization of fluids trapped in the pore spaces of the gouge (e.g., Rowe et al, 2012) or focused injection of pressurized fluids from the fault surroundings during rupture propagation (e.g., Sibson, 1990; Fondriest et al., 2012). The fluidized features in the VCFZ compare well with laminar grain flow layers characterized by grain preferred orientation parallel to the fault surface (Rowe and Griffith, 2015). Consequently, the presence of calcite-cemented cataclasite and the occurrence of laminar grain flow structures in the slipping zones along the master fault suggest the presence of pressurized fluids during seismic faulting along the VCFZ. 


\subsection{Implications for the interpretation of seismicity in the Central Apennines}

In the previous sections we documented the evidence of seismic rupture propagation within

the footwall of the VCFZ and the occurrence of both inherited compressional- and present active extensional- structures. Here we relate these structural features to the active fault network inferred from high-precision hypocenter relocations for the L'Aquila 2009 seismic sequence by Valoroso et al. $(2013 ; 2014)$.

In the case of the L'Aquila 2009 earthquake sequence (mainshock $M_{\mathrm{W}} 6.1$ April 6, 2009), Valoroso et al. $(2013 ; 2014)$ depicted the seismic faults of the area by means of high-precision relocation of $\sim 64,000$ events, both foreshocks and mostly aftershocks during 2009, with a completeness magnitude of 0.7 (Fig. 13a). The relative hypocenter location precision was smaller than the dimension of seismic ruptures (e.g., $~ 30 \mathrm{~m}$ for $\mathrm{M}_{\mathrm{L}}=1.0$, Sibson, 1989) with a precision ranging from few meters to tens of meters. The L'Aquila Fault, responsible for the mainshock, was described as a fault striking NW-SE and dipping $50^{\circ}$ towards $\mathrm{SW}$ for a length of about $18 \mathrm{~km}$ (Valoroso et al., 2013). In particular, in its central sector the L'Aquila Fault is imaged as a fault zone dipping at high angle $\left(\sim 55^{\circ}\right)$ towards SW and cutting at 3-5 km depth a well-defined fault structure dipping at low angle $\left(\sim 15^{\circ}\right)$ (i.e., the dashed green line in Fig. 13b) towards SW (Fig. 13ab). The possible focal mechanism solutions on the low-angle structure are consistent either with a low-angle plane dipping towards SW or with a series of closely spaced high-angle planes dipping towards NE. Some authors (Chiaraluce et al., 2011; Valoroso et al., 2013) interpreted the low-angle planes as the shallow flat portions of a thrust inherited from the Miocene-Pliocene compressional phase. The thrust has been reactivated as a low-angle extensional fault during the Present extension 691 (Speranza et al., 2003). Moreover, the projection of this plane to the surface, coincides with the central sector of the GSM (Chiaraluce et al., 2011). This fault network imaged by seismic inversion 
are reactivated as (minor, at least in terms of displacement) extensional faults (Figs. 6b-c) and a major extensional Andersonian-type fault cuts the older thrust zone (Fig. 13c-d). with strike-slip focal mechanism solutions (13\%) typically located at linkage areas between fault segments. A minor occurrence of compressive earthquakes (i.e., thrust and transpressive, 5\%) is dispersed in the fault system. This distribution compares well with the kinematics measured on fault surfaces in the VCFZ. Although evidence of extension-related thrust kinematics was not found, extensional and transtensional faults were the most recurrent structures. Moreover, strike-slip kinematics were associated with faults interpreted as kinematic tears.

Therefore, all the documented similarities between the VCFZ and the buried structures activated during the L'Aquila 2009 seismic sequence described through seismological techniques (Chiaraluce et al., 2011; Valoroso et al., 2013, 2014) allow the VCFZ to be considered a valid exhumed analog of the structures responsible for the present seismicity in the Central Apennines.

\section{Conclusions}

The active Campo Imperatore Fault System (CIFS) cuts the dolostones bounding the inner part of the Gran Sasso Massif in the Italian Central Apennines. The exposed segment of the VCFZ strikes about SE-NW (i.e., sub-parallel to the main seismogenic faults of the Central Apennines) cuts through dolostones and limestones, accommodated about $2 \mathrm{~km}$ of maximum vertical throw and

Within the VCFZ we mapped five main structural units based on fault zone rocks and damage intensity: namely they are the Low Strain Damage Zone, the High Strain Damage Zone, the 
cataclastic dolostones in the footwall. Faults in the footwall are mainly synthetic and antithetic to

721 the master fault, but a set of NE-SW trending strike-slip faults are well exposed in the upper part of the creek and interpreted as kinematic tears. The spatial distribution of the fault and fracture network affecting the VCFZ suggest a close relationship between these structural units and extensional deformation active in the area since Early Pleistocene times. However, dolomitization in the Breccia Unit occurred along the damage zone of a shallow-dipping thrust juxtaposing the Lower Jurassic Calcare Massiccio Fm. onto the Middle Jurassic Verde Ammonitico Fm. The same thrust zone, not affected by dolomitization, is exposed immediately to the East of the VCFZ. This evidence, coupled with the attitude parallel to low-angle bedding surfaces of dolomite veins in the Breccia Unit, and the systematic deformation of Breccia Unit rocks by cataclasis on the extensional master fault and subsidiary ones, indicate that dolomitization was syn- or post-thrusting, but occurred still during the contractional regime, before regional extension affected the area. The presence of a continuous $\sim 40 \mathrm{~m}$ thick band of Cataclastic Unit 1 lining the master fault is interpreted as the result of in-situ shattering due to the propagation of multiple seismic ruptures and subsequent slip localization and cementation along a multitude of subsidiary faults. Past seismic behavior of the exposed faults is suggested by the occurrence of mirror-like slip surfaces truncating dolomite grains, foam-like textures in the sheared calcite-bearing veins and in-situ shattering associated with mirror-like slip surfaces and fluidized cataclasites.

For the L'Aquila 2009 seismic sequence, high-precision hypocenter relocation imaged a fault network characterized by a principal high-angle fault cutting a low-angle plane at shallow depth (3-5 km). The low-angle plane was interpreted as a flat portion of a thrust inherited from the compressional phase during Miocene-Pliocene and exploited as low-angle extensional fault during Present extension. This structural setting compares well with the reactivation of thrust-related features and fault network geometry described in the VCFZ. Therefore, the VCFZ provides a suitable exhumed analog of seismically active buried fault zones in the Central Apennines, such as those that caused the L'Aquila 2009 seismic sequence. 


\section{Acknowledgements}

748 The authors are greatly indebted with the "Ente Parco Nazionale del Gran Sasso e Monti della 749 Laga" for allowing us to conduct field work in the Campo Imperatore area and the Regione 750 Abruzzo for the aerial photographs. The Hotel Campo Imperatore staff is warmly acknowledged for 751 support during field work. F. Calamita is thanked for sending to the authors a preliminary version of 752 the Foglio 349 "Gran Sasso d'Italia”; M. Massironi, A. Traforti, S. Gori, E. Falcucci, P. Burrato, D. 753 Pantosti, L. Cardello and F. Agosta are thanked for discussions. The authors warmly thank 754 Telemaco Tesei and Rachael Bullock for their thoughtful revisions that contributed to improving 755 the quality of the manuscript. The authors thank L. Tauro and E. Masiero (thin section preparation), 756 F. Zorzi (XRPD analysis) and S. Castelli (high-resolution scans of thin sections). The authors 757 contributions are as follows: MD, MF, LC, FB, FS and GDT: field data; MD and AB: 758 photogrammetry and fracture abundance; MD, MF and GDT: optical and scanning electron 759 microscopy. MD wrote the first version of the draft; all authors contributed to the manuscript. This 760 research was funded by the European Research Council Consolidator Grant Project (NOFEAR) No 761614705 (MD, MF and GDT). 
References

Aben, F. M., Doan, M. $\square$ L., Mitchell, T. M., Toussaint, R. Reuschlé, T ., Fondriest, M., Gratier, J. $\square$

P., Renard, F., 2016. Dynamic fracturing by successive coseismic loadings leads to pulverization in active fault zones. J. Geophys. Res., 121, 2338-2360.

Adamoli, L., Calamita, F., Pelorosso, M., 2003. Itinerario $N^{\circ} 2$ - Gran Sasso d'Italia: dai Prati di

Tivo ai Prati di Tivo attraverso il ghiacciaio del Calderone, il Corno Grande, Campo Pericoli e la

Val Maone. In: Guide Geologiche Regionali, Abruzzo: 102-112, BE-MA ed., Lodi (MI).

Adamoli, L., Calamita, F., Pizzi, A., 2012. Note Illustrative del Foglio 349 "G. Sasso" della Carta

Geologica d'Italia alla scala $1: 50.000$. ISPRA, Roma

Agosta, F., Aydin, A., 2006. Architecture and deformation mechanism of a basin-bounding normal fault in Mesozoic platform carbonates, central Italy. J. Struct. Geol. 28 (8), 1445-1467.

Agosta, F., Kirschner, D., 2003. Fluid conduits in carbonate-hosted seismogenic normal faults of central Italy. J. Geophys. Res. 108 (B4), 2221. http://dx.doi.org/10.1029/2002JB002013.

Allam, A. A., Ben-Zion, Y., 2012. Seismic velocity structures in the Southern California plate784

Alvarez, W., Engelder, T., Geiser, P. A., 1978. Classification of solution cleavage in pelagic limestones. Geology, 6(5), 263-266. 
Aydin, A., Antonellini, M., Tondi, E., Agosta, F., 2010. Deformation along the leading edge of the

Maiella thrust sheet in Central Italy. J. Struct. Geol. 32, 1291-1304.

Bai, T., Pollard, D. D., 2000. Fracture spacing in layered rocks: a new explanation based on the stress transition. J. Struct. Geol. 22 (1), 43-57.

Ben-Zion, Y., Shi, Z., 2005. Dynamic rupture on a material interface with spontaneous generation of plastic strain in the bulk. Earth Planet. Sci. Lett. 236, 489-496.

Billi, A., Salvini, F., Storti, F., 2003. The damage zone-fault core transition in carbonate rocks: implications for fault growth, structure and permeability. J. Struct. Geol. 25 (11), 1779-1794.

Billi, A., Storti, F., 2004. Fractal distribution of particle size in carbonate cataclastic rocks from the core of a regional strike-slip fault zone. Tectonophysics 384 (1), 115-128.

Bistacchi, A., Massironi, M., Menegon, L., 2010. Three-dimensional characterization of a crustalscale fault zone: The Pusteria and Sprechenstein fault system (Eastern Alps). J. Struct. Geol. 32, 2022-2041.

Boccaletti, M., Elter, P., Guazzone, G., 1971. Plate tectonic models for the development of the 809

810 Bonson, C. G., Childs, C., Walsh, J. J., Schöpfer, M. P., Carboni, V., 2007. Geometric and 811 kinematic controls on the internal structure of a large normal fault in massive limestones: the Maghlaq Fault, Malta. J. Struct. Geol. 29 (2), 336-354. 
Bouchon, M., Vallee, M., 2003. Observation of Long Supershear Rupture During the Magnitude 8.1

815 Kunlunshan Earthquake. Science, 301, 824-826.

816

817 Brodsky, E.E., Rowe, C.D., Meneghini, F., Moore, J.C., 2009. A geological fingerprint of low818 viscosity fault fluids mobilized during an earthquake. J. Geophys. Res. 114, B01303.

Brune, J. N., 2001. Fault normal dynamic loading and unloading: an explanation for "nongouge',rock powder and lack of fault-parallel shear bands along the San Andreas fault. Eos Trans. AGU 82 (47). Fall Meet. Suppl., Abstract S22B-0655.

Buiter, S. J. H., Wortel, M. J. R., Govers, R., 1998. The role of subduction in the evolution of the Apennines foreland basin. Tectonophysics 296 (3), 249-268.

826

Bullock, R. J., De Paola, N., Holdsworth, R. E., Trabucho-Alexandre, J., 2014. Lithological controls on the deformation mechanisms operating within carbonate-hosted faults during the seismic cycle. J. Struct. Geol. 58, 22-42.

Burchfiel, B. C., Nakov, R., Dumurdzanov, N., Papanikolaou, D., Tzankov, T., Serafimovski, T.,

King, R. W., Kotzev, V., Todosov, A., Nurce, B., 2008. Evolution and dynamics of the Cenozoic tectonics of the South Balkan extensional system. Geosphere, 4(6), 919-938.

835 Caine, J. S., Evans, J. P., Forster, C. B., 1996. Fault zone architecture and permeability structure. 836 Geology, 24 (11), 1025-1028. 
Calamita, F., Di Domenica, A., Viandante, M.G., Tavarnelli, E., 2008. Sovrascorrimenti younger on older o faglie normali ruotate: la linea Vallepietra-Filettino-Monte Ortara (Appennino centrale laziale-abruzzese). Rend. Online SGI, 1, Note Brevi, p. 43-47, 5 figg.

Calamita, F., Paltrinieri, W., Pelorosso, M., Scisciani, V., Tavarnelli, E., 2003b. Inherited Mesozoic architecture of the Adria continental palaeomargin in the Neogene central Apennines orogenic system, Italy, Boll. Soc. Geol. Ital. 122, 307-318.

845

846 Calamita, F., Pelorosso, M., Satolli, S., 2003a. The role of the Adria Mesozoic paleomargin 847 architecture on the Gran Sasso d'Italia orogenic system (central Apennines), Boll. Soc. Geol. Ital. $122,337-349$.

Cardello, G., Doglioni, C., 2014. From Mesozoic rifting to Apennine orogeny: The Gran Sasso range (Italy). Gondwana Res. doi:10.1016/j.gr.2014.09.009.

Carminati, E., Lustrino, M., Doglioni, C., 2012. Geodynamic evolution of the central and western

Mediterranean: Tectonics vs. igneous petrology constraints. Tectonophysics 579, 173-192.

Chester, F., Logan, J., 1986. Implications for mechanical properties of brittle faults from observations of the Punchbowl fault zone, California. Pure and Applied Geophysics, 124(1-2), 79106.

860 Chiarabba, C., Amato, A., Anselmi, M., Baccheschi, P., Bianchi, I., Cattaneo, M., Cecere, G., 861 Chiaraluce, L., Ciaccio, M.G., De Gori, P., De Luca, G., Di Bona, M., Di Stefano R., Faenza, L., 862 Govoni, A., Improta, L., Lucente, F.P., Marchetti, A., Margheriti, L., Mele, F., Michelini, A., 863 Monachesi, G., Moretti, M., Pastori, M., Piana Agostinetti, N., Piccinini, D., Roselli, P., Seccia, D., 
Valoroso, L., 2009. The 2009 L'Aquila (central Italy) Mw6. 3 earthquake: Main shock and aftershocks. Geophys. Res. Lett. 36 (18), L18308. http://dx.doi.org/10.1029/2009GL039627.

867 Chiaraluce, L., 2012. Unravelling the complexity of Apenninic extensional fault systems: A review 868 of the 2009 L'Aquila earthquake (Central Apennines, Italy). J. Struct. Geol. 42, 2-18.

870 Chiaraluce, L., Valoroso, L., Piccinini, D., Di Stefano, R., De Gori, P., 2011. The anatomy of the 871 2009 L'Aquila normal fault system (central Italy) imaged by high resolution foreshock and aftershock locations. J. Geophys. Res. 116 (B12). http://dx.doi.org/10.1029/2011JB008352.

Childs, C., Manzocchi, T., Walsh, J. J., Bonson, C. G., Nicol, A., Schöpfer, M. P., 2009. A 875 geometric model of fault zone and fault rock thickness variations. J. Struct. Geol. 31 (2), 117-127.

876

877 Cladouhos, TT, 1999. Shape preferred orientations of survivor grains in fault gouge. J. Struct. Geol. 878 $21,419-436$.

880 Clemenzi, L., Storti, F., Balsamo, F., Molli, G., Ellam, R., Muchez, P., Swennen, R., 2015. Fluid 881 pressure cycles, variations in permeability, and weakening mechanisms along low-angle normal 882 faults: The Tellaro detachment, Italy. Geological Society of America Bulletin, 127(11-12), 16898831710.

885 Collettini, C., Viti, C., Tesei, T., Mollo, S., 2013. Thermal decomposition along natural carbonate 886 faults during earthquakes. Geology, 41(8), 927-930. 
Collettini, C., Carpenter, B. M., Viti, C., Cruciani, F., Mollo, S., Tesei, T., Trippetta, F., Valoroso,

889 L., Chiaraluce, L., 2014. Fault structure and slip localization in carbonate-bearing normal faults: An 890 example from the Northern Apennines of Italy. J. Struct. Geol. 67, 154-166.

891

D’Agostino, N., Chamot-Rooke, N., Funiciello, R., Jolivet, L., Speranza, F., 1998. The role of preexisting thrust faults and topography on the styles of extension in the Gran Sasso range (central Italy). Tectonophysics 292, 229-254.

895

De Paola, N., Chiodini, G., Hirose, T., Cardellini, C., Caliro, S., Shimamoto, T., 2011. The 897 geochemical signature caused by earthquake propagation in carbonate-hosted faults. Earth Planet.

Sci. Lett. 310 (3), 225-232.

899

De Paola, N., Holdsworth, R. E., Viti, C., Collettini, C., Bullock, R., 2015. Can grain size sensitive 901

flow lubricate faults during the initial stages of earthquake propagation?. Earth Planet. Sci. Lett.

Dershowitz, W.S., Herda, H.H., 1992. Interpretation of fracture spacing and intensity. In:Tillerson,

J.R., Wawersik, W.R. (Eds.), Proceedings of the $33^{\text {rd }}$ U.S. Symposium on Rock Mechanics.

Destro, N., 1995. Release fault: A variety of cross fault in linked extensional fault systems, in the 910

911 Di Bucci, D., Mazzoli, S., 2003. The October-November 2002 Molise seismic sequence (southern 912 Italy): an expression of Adria intraplate deformation. Journal of the Geological Society, 160(4), $913 \quad 503-506$. 
915 Di Stefano, R., Chiarabba, C., Chiaraluce, L., Cocco, M., De Gori, P., Piccinini, D., Valoroso, L., 916 2011. Fault zone properties affecting the rupture evolution of the 2009 (Mw 6.1) L'Aquila 917 earthquake (central Italy): Insights from seismic tomography. Geophys. Res. Lett. 38 (10). 918 doi:10.1029/2011GL047365.

919

920 Di Toro, G., Han, R., Hirose, T., De Paola, N., Nielsen, S., Mizoguchi, K., Ferri, F., Cocco, M., 921 Shimamoto, T., 2011. Fault lubrication during earthquakes. Nature 471 (7339), 494-498.

922

923 Di Toro, G., Spagnuolo, E., Violay, M., Rempe, M., Smith, S.A.F., Nielsen, S., Fondriest, M., 924 Plümper, O., 2015. "Frictional processes" in carbonate-bearing rocks at seismic deformation 925 conditions. American Geophysical Union Annual Meeting, AGU2015 Abstracts with Programme 926 MR31B-01.

928 Doan, M.-L., d'Hour, V., 2012. Effect of initial damage on rock pulverization along faults. J. Struct. 929 Geol. 45, 113-124.

931 Doan, M.-L., Gary, G., 2009. Rock pulverization at high strain rate near the San Andreas Fault. Nat. 932 Geosci. 2, 709-712.

934 Dor, O., Ben-Zion, Y., Rockwell, T.K., Brune, J., 2006b. Pulverized rocks in the Mojave section of 935 the San Andreas fault zone. Earth Planet. Sci. Lett. 245, 642-654.

937 Dor, O., Rockwell, T.K., Ben-Zion, Y., 2006a. Geological observations of damage asymmetry in 938 the structure of the San Jacinto, San Andreas and Punchbowl faults in Southern California: a 
possible indicator for preferred rupture propagation direction. Pure Appl. Geophys. 163, 301-349.

940 http://dx.doi.org/10.1007/s00024-005-0023-9.

Elter, P., Giglia, G., Tongiorni, M., Trevisan, L. 1975. Tensional and compressional areas in recent

943 (Tortonian to present) evolution of Northern Apennines. Boll. Geofis. Teor. Appl. 42, 3-18.

945 Faulkner, D. R., Lewis, A. C., Rutter, E. H., 2003. On the internal structure and mechanics of large 946 strike-slip fault zones: field observations of the Carboneras fault in southeastern Spain. 947 Tectonophysics 367 (3), 235-251. http://dx.doi.org/10.1016/S0040-1951(03)00134-3.

949 Faulkner, D., Jackson, C., Lunn, R., Schlische, R., Shipton, Z., Wibberley, C., Withjack, M., 2010. 950 A review of recend development concerning the structure, mechanics and fluid flow properties of 951 fault zones. J. Struct. Geol. 32(11), 1557-1575.

953 Fondriest, M., Aretusini, S., Di Toro, G., Smith, S.A.F., 2015. Fracturing and rock pulverization 954 along an exhumed seismogenic fault zone in dolostones: The Foiana Fault Zone (Southern Alps, 955 Italy). Tectonophysics 654, 56-74.

957 Fondriest, M., Smith, S.A.F., Candela, T., Nielsen, S., Mair, K., Di Toro, G., 2013. Mirror-like 958 faults and power dissipation during earthquakes. Geology 41, 1175-1178.

960 Fondriest, M., Smith, S.A.F., Di Toro, G., Zampieri, D., Mittempergher, S., 2012. Fault zone 961 structure and seismic slip localization in dolostones, an example from the Southern Alps, Italy. J. 962 Struct. Geol. 45, 52-67. 
964 Fossen, H., Schultz, R. A., Shipton, Z. K., Mair, K., 2007. Deformation bands in sandstone: a 965 review. J. Geol. Soc. 164 (4), 755-769.

967 Galadini, F., 1999. Pleistocene changes in the central Apennine fault kinematics: a key to decipher 968 active tectonics in central Italy. Tectonics 18 (5), 877-894.

970 Galadini, F, Galli, P, Moro, M, 2003. Paleoseismology of silent faults in the central Apennines 971 (Italy): the Campo Imperatore fault (Gran Sasso Range fault system). Ann. Geophys. 46 (5), 793 972813.

974 Galli, P., Galadini, F., Moro, M., Giraudi, C., 2002. New paleoseismological data from the Gran 975 Sasso d'Italia area (central Apennines). Geophys. Res. Lett. 29 (7), 38-1.

977 Ghisetti, F., Vezzani, L., 1981. Contribution of structural analysis to understanding the geodynamic 978 evolution of the Calabrian Arc (Southern Italy). J. Struct. Geol. 3 (4), 371-381.

980 Ghisetti, F., Vezzani, L., 1991. Thrust belt development in the central Apennines (Italy): Northward 981 polarity of thrusting and out $\square$ of $\square$ sequence deformations in the Gran Sasso Chain. Tectonics 10, $982904-919$.

984 Ghisetti, F., Vezzani, L., 1999. Depth and modes of Pliocene-Pleistocene crustal extension of the 985 Apennines (Italy). Terra Nova 11, 67-72.

987 Giraudi, C., Frezzotti, M., 1995. Palaeoseismicity in the Gran Sasso Massif (Abruzzo, central Italy). 988 Quaternary Int. 25, 81-93. 
990 Giraudi, C., Frezzotti, M., 1997. Late Pleistocene glacial events in the central Apennines, Italy.

991 Quaternary Res. 48 (3), 280-290.

992

993 Gratier, J. P., Gamond, J. F., 1990. Transition between seismic and aseismic deformation in the 994 upper crust. Geological Society, London, Special Publications, 54(1), 461-473.

996 Green II, H.W., Shi, F., Bozhilov, K., Xia, G., Reches, Z., 2015. Phase transformation and 997 nanometric flow cause extreme weakening during fault slip. Nat. Geosci. 8, 484-489-

999 ISIDe Working Group, 2010. Italian Seismological Instrumental and parametric database. 1000 http://iside.rm.ingv.it/iside/standard/index.jsp.

Ispra, 2012. Carta Geologica d'Italia, sheet 349 “Gran Sasso d'Italia”. APAT, Servizio Geologico 1003 d'Italia. S.EL.CA., Florence, Italy.

1004 http://www.isprambiente.gov.it/Media/carg/349_GRANSASSO/Foglio.html.

Jolivet, L., Faccenna, C., 2000. Mediterranean extension and the Africa-Eurasia collision. 1007 Tectonics $19(6), 1095-1106$.

1009 Jolivet, L., Faccenna, C., Goffé, B., Mattei, M., Rossetti, F., Brunet, C., Storti, F., Funiciello, R., 1010 Cadet, J.P., D’Agostino, N., Parra, T., 1998. Midcrustal shear zones in postorogenic extension: 1011 example from the northern Tyrrhenian Sea. J. Geophys. Res. 103 (B6), 12123-12160.

1013 Lavecchia, G., 1985. Il sovrascorrimento dei Monti Sibillini; analisi cinematica e strutturale. 1014 Bollettino della Società Geologica Italiana, 104(1), 161-194. 
1016 Ma, S., Andrews, D.J., 2010. Inelastic off-fault response and three-dimensional dynamics of 1017 earthquake rupture on a strike-slip fault. J. Geophys. Res. 115. 1018 http://dx.doi.org/10.1029/2009JB006382.

1020 Malinverno, A., Ryan, W. B., 1986. Extension in the Tyrrhenian Sea and shortening in the 1021 Apennines as result of arc migration driven by sinking of the lithosphere. Tectonics 5 (2), 227-245.

1023 Micarelli, L., Benedicto, A., Wibberley, C. A. J., 2006. Structural evolution and permeability of 1024 normal fault zones in highly porous carbonate rocks. J. Struct. Geol. 28 (7), 1214-1227.

1026 Michie, E. A. H., Haines, T. J., Healy, D., Neilson, J. E., Timms, N. E., Wibberley, C. A. J., 2014. 1027 Influence of carbonate facies on fault zone architecture. J. Struct. Geol. 65, 82-99.

1029 Mitchell, T. M., Ben-Zion, Y., Shimamoto, T., 2011. Pulverized fault rocks and damage asymmetry 1030 along the Arima-Takatsuki Tectonic Line, Japan. Earth Planet. Sci. Lett. 308, 284-297. 1031 http://dx.doi.org/10.1016/j.epsl.2011.04.023.

1033 Mitchell, T. M., Faulkner, D. R., 2009. The nature and origin of off-fault damage surrounding 1034 strike-slip fault zones with a wide range of displacements: a field study from the Atacama fault 1035 system, northern Chile. J. Struct. Geol. 31 (8), 802-816. http://dx.doi.org/10.1016/j.jsg.2009.05.002.

1037 Mitchell, T. M., Smith, S.A.F., Anders, M. H., Di Toro, G., Nielsen, S., Cavallo, A., Beard, A. D., 1038 2015. Catastrophic emplacement of giant landslides aided by thermal decomposition: Heart 1039 Mountain, Wyoming. Earth Planet. Sci. Lett. 411, 199-207. 
1041 Molli, G., Malavieille, J., 2011. Orogenic processes and the Corsica/Apennines geodynamic 1042 evolution: insights from Taiwan. Int. J. Earth Sci. 100 (5), 1207-1224.

1043

1044 Mort, K., Woodcock, N. H., 2008. Quantifying fault breccia geometry: Dent fault, NW England. J. 1045 Struct. Geol. 30, 701-709. http://dx.doi.org/10.1016/j.jsg.2008.02.005.

1047 Parotto, M., Praturlon, A., 1975. Geological summary of the Central Apennines. Quaderni della 1048 Ricerca Scientifica 90, 257-300.

Passchier, C.W., Trouw, R.A.J., 2005. Microtectonics, 2nd edition. Springer-Verlag, Berlin.

Patacca, E., Sartori, R., Scandone, P., 1990. Tyrrhenian basin and Apenninic arcs: kinematic 1053 relations since late Tortonian times. Mem. Soc. Geol. It. 45 (1), 425-451.

Paterson, M. S., 1958. Experimental deformation and faulting in Wombeyan marble. Geological

Society of America Bulletin, 69(4), 465-476.

Rosenbaum, G., Lister, G.S., 2004. Neogene and Quaternary rollback evolution of the Tyrrhenian 1059

Sea, the Apennines, and the Sicilian Maghrebides. Tectonics 23 (1), TC1013. doi:1010.1029/2003TC001518.

Rowe, C.D., Fagereng, A., Miller, J.A., Mapani, B., 2012. Signature of coseismic decarbonation in dolomitic fault rocks of the Naukluft Thrust, Namibia. Earth Planet. Sci. Lett. 333-334, 200-210. 
1068 Rutter, E. H., 1983. Pressure solution in nature, theory and experiment. Journal of the Geological 1069 Society, 140(5), 725-740.

1071 Sani, F., Ventisette, C., Montanari, D., Coli, M., Nafissi, P., Piazzini, A., 2004. Tectonic evolution 1072 of the internal sector of the Central Apennines, Italy. Mar. Pet. Geol. 21, 1235-1254. 1073

1074 Santantonio, M., Carminati, E., 2011. Jurassic rifting evolution of the Apennines and Southern Alps 1075 (Italy): parallels and differences. Geol. Soc. Am. Bull. 123 (3-4), 468-484.

1077 Schaff, D. P., Bokelmann, G. H., Beroza, G. C., Waldhauser, F., Ellsworth, W. L., 2002. High1078 resolution image of Calaveras Fault seismicity. J. Geophys. Res. 107 (B9), ESE-5.

Schröckenfuchs, T., Bauer, H., Grasemann, B., Decker, K., 2015. Rock pulverization and 1081 localization of a strike-slip fault zone in dolomite rocks (Salzach-Ennstal-Mariazell-Puchberg 1082 fault, Austria). J. Struct. Geol. 78, 67-85.

1084 Shipton, Z. K., Soden, A. M., Kirkpatrick, J. D., Bright, A. M., Lunn, R. J., 2006. How thick is a 1085 fault? Fault displacement-thickness scaling revisited. Geophysical Monograph Series, 170, 193-198. 1086

1087 Sibson, R., 1977, Fault rocks and fault mechanisms, J. Geol. Soc. 133, 191-213. 1088 1089 Sibson, R. H., 1989. Earthquake faulting as a structural process. J. Struct. Geol. 11(1), 1-14. 1090 http://dx.doi.org/10.1016/0191-8141(89)90032-1. 
1092 Sibson, R. H., 1990. Conditions for fault-valve behaviour. In: Knipe, R.J., Rutter, E.H. (Eds.), 1093 Deformation Mechanisms, Rheology and Tectonics. Geological Society London, Special 1094 Publications 54 (1), 15-28.

Sibson, R. H., 2003. Thickness of the seismic slip zone. Bull. Seismol. Soc. Am. 93 (3), 1169-1178. 1097 http://dx.doi.org/10.1785/0120020061.

Siman-Tov, S., Aharonov, E., Boneh, Y., \& Reches, Z. E., 2015. Fault mirrors along carbonate faults: Formation and destruction during shear experiments. Earth Planet. Sci. Lett. 430, 367-376.

Siman-Tov, S., Aharonov, E., Sagy, A., Emmanuel, S., 2013. Nanograins form carbonate 909 fault mirrors, Geology 41, 703-706. doi:10.1130/G34087.1.

Smith, S.A.F., Billi, A., Di Toro, G., Spiess, R., 2011. Principal Slip Zones in Limestone:

Microstructural Characterization and Implications for the Seismic Cycle (Tre Monti Fault, Central Apennines, Italy). Pure Appl. Geophys. 168, 2365-2393.

Smith, S.A.F., Di Toro, G., Kim, S., Ree, J.-H., Nielsen, S., Billi, A., Spiess, R., 2013. Coseismic recrystallization during shallow earthquake slip, Geology 41, 63-66. doi:10.1130/G33588.1.

Smith, S.A.F., Griffith, J.R., Fondriest, M., Di Toro, G., 2016. "Coseismic foliations” in gouge and 1113 cataclasite: experimental observations and consequences for interpreting the fault rock record. In: 1114 Thomas, M., Bath, H., Mitchell, T. (Eds.), Fault-zone Properties and Earthquake Rupture 1115 Dynamics. Geophysical Monograph Series, American Geophysical Union Special Volume, 1116 Washington D.C., USA, in press. 
1118 Smith, S.A.F., Nielsen, S., Di Toro, G., 2015. Strain localization and the onset of dynamic

1119 weakening in calcite fault gouge. Earth Planet. Sci. Lett. 413, 25-36.

1121 Speranza, F., 2003. Passive-margin heritage on thrust-system development: evidence from Corno 1122 Grande (Gran Sasso range, Italy). Boll. Soc. Geol. It. 122, 233-249, 13 ff.

1124 Speranza, F., Adamoli, L., Maniscalco, R., Florindo, F., 2003. Genesis and evolution of a curved 1125 mountain front: paleomagnetic and geological evidence from the Gran Sasso range (central 1126 Apennines, Italy). Tectonophysics 362, 183-197.

1128 Speranza, F., Minelli, L., 2014. Ultra $\square$ thick Triassic dolomites control the rupture behavior of the 1129 central Apennine seismicity: Evidence from magnetic modeling of the L'Aquila fault zone. J. 1130 Geophys. Res. 119, 6756-6770.

1132 Storti, F., Aldega, L., Balsamo, F., Corrado, S., Del Monaco, F., Di Paolo, L., Mastalerz, M., 1133 Monaco, P., Tallini, M., 2013. Evidence for strong middle Pleistocene earthquakes in the epicentral 1134 area of the 6 April 2009 L'Aquila seismic event from sediment paleofluidization and 1135 overconsolidation. J. Geophys. Res. 118 (7), 3767-3784.

1137 Storti, F., Balsamo, F., Salvini, F., 2007. Particle shape evolution in natural carbonate granular wear 1138 material. Terra Nova 19 (5), 344-352.

1140 Tesei, T., Collettini, C., Viti, C., Barchi, M. R., 2013. Fault architecture and deformation 1141 mechanisms in exhumed analogues of seismogenic carbonate-bearing thrusts. J. Struct. Geol. 55, 1142 167-181. 
1144 Tesei, T., Collettini, C., Barchi, M. R., Carpenter, B. M., Di Stefano, G., 2014. Heterogeneous

1145 strength and fault zone complexity of carbonate-bearing thrusts with possible implications for 1146 seismicity. Earth Planet. Sci. Lett. 408, 307-318.

1148 Valoroso, L., Chiaraluce, L., Collettini, C., 2014. Earthquakes and fault zone structure. Geology 42, 1149 343-346.

1151 Valoroso, L., Chiaraluce, L., Piccinini, D., Stefano, R., Schaff, D., Waldhauser, F., 2013. 1152 Radiography of a normal fault system by 64,000 high $\square$ precision earthquake locations: The 11532009 L'Aquila (central Italy) case study. J. Geophys. Res. 118, 1156-1176.

1155 Verberne, B. A., He, C., Spiers, C. J., 2010. Frictional properties of sedimentary rocks and natural 1156 fault gouge from the Longmen Shan fault zone, Sichuan, China. Bulletin of the Seismological 1157 Society of America, 100(5B), 2767-2790.

1159 Verberne, B.A., Spiers, C.J., Niemeijer, A.R., De Bresser, J.H.P., De Winter, D.A.M., Plümper, O., 1160 2013. Frictional Properties and Microstructure of Calcite-Rich Fault Gouges Sheared at Sub1161 Seismic Sliding Velocities. Pure Appl. Geophys. 1-24. http://dx.doi.org/10.1007/s00024-013- 076011620.

1164 Vezzani, L., Festa, A., Ghisetti, F.C., 2010. Geology and tectonic evolution of the Central-Southern 1165 Apennines, Italy. Geol. Soc. Am. Special Papers 469, 1-58.

1167 Viti, C., Collettini, C., Tesei, T., 2014. Pressure solution seams in carbonatic fault rocks: 1168 mineralogy, micro/nanostructures and deformation mechanism. Contribution to Mineralogy and 1169 Petrology, 167(2), 1-15. 
1171 Waldhauser, F., Ellsworth, W.L., 2000. A double-difference earthquake location algorithm: Method 1172 and application to the northern Hayward fault, California. Bull. Seismol. Soc. Am. 90 (6), 135311731368.

1175 Wibberley, C.A., Shimamoto, T., 2003. Internal structure and permeability of major strike-slip fault 1176 zones: the Median Tectonic Line in Mie Prefecture, Southwest Japan. J. Struct. Geol. 25 (1), 59-78.

1178 Wibberley, C. A., Yielding, G., Di Toro, G., 2008. Recent advances in the understanding of fault 1179 zone internal structure: a review. Geological Society, London, Special Publications, 299(1), 5-33.

1181 Willemse, E. J., Peacock, D. C., Aydin, A., 1997. Nucleation and growth of strike-slip faults in 1182 limestones from Somerset, UK. Journal of Structural Geology, 19(12), 1461-1477.

1184 Wojtal, S., Mitra, G., 1986. Strain hardening and strain softening in fault zones from foreland 1185 thrusts. Geological Society of America Bulletin, 97(6), 674-687.

1187 Yuan, F., Prakash, V., Tullis, T., 2011. Origin of pulverized rocks during earthquake fault rupture.

1188 J. Geophys. Res. 116, B06309. http://dx.doi.org/10.1029/2010JB007721. 
Figure captions

Figure 1. Geological setting of the Campo Imperatore area. (a) Structural map of the Gran Sasso area (modified after Storti et al., 2013). (b) Geological map of the study area simplified after the published Foglio 349 "Gran Sasso d'Italia" (Ispra, 2012). Quaternary colluvial deposits are the infilling of the Campo Imperatore intramontane basin and correspond to the non-colored areas. NNE-SSW striking normal faults dissect and displace the thrust system. The Omo Morto thrust fault runs on the northern side of Mt. Aquila and disappears before Vado di Corno, where the fault zone (VCFZ) is exposed within badlands. (c) Stratigraphic column of the Campo Imperatore area (modified after Cardello and Doglioni, 2014). (d) Geological cross section across the Campo 1200 Imperatore intramontane basin (modified after Ispra, 2012). To the NE of the Mt. Brancastello 1201 strata at the hangingwall of the thrust are overturned, while in the Campo Imperatore plain normal faults cut and dislocate the thrust system. (e) Stereographic projection of bedding surfaces measured within the VCFZ result in a monocline with constant attitude of $\mathrm{N} 270 / 20^{\circ}$ (stereographic projection 1204 in the figure is equal area, lower hemisphere).

Figure 2. Structural map and geological section of the study area. (a) The structural map shows the distribution of principal fault strands (ticks on faults are drawn on the downthrown side) and structural units distinguished within the footwall block of the Vado di Corno Fault Zone. The base of the creek is marked by the master fault, which is lined by the cataclastic units. A tens of meters 1210 thick lithon of Low Strain Damage Zone is found at about $50 \mathrm{~m}$ from the master fault. The Breccia 1211 Unit outcrops both at the bottom of the creek in the center of the map and in contact with the 1212 Cataclastic Unit 1 to the SW. The High Strain Damage Zone comprises most of the fault zone in 1213 terms of rock volumes. (b) A geological section oriented orthogonal to the master fault $\left(\mathrm{N} 30^{\circ} \mathrm{E}\right)$ 1214 shows how the structural units are typically associated and bounded by the normal faults with the 
exception of the Breccia Unit, which dips at low angle and outcrops where the creek is more eroded. The axes are in scale $\mathrm{X}: \mathrm{Y}=1: 2$.

Figure 3. Core of the Vado di Corno Fault Zone. (a) The structural units distinguished in the footwall block of the VCFZ show a great variability in appearance due to changes in the bulk deformation intensity and deformation processes. (b) The base of the badlands is marked by the contact between the Quaternary deposits in the hangingwall (reddish in color) and the cataclasites in the footwall (white in color) along the master fault. (c) The core of the master fault is $<20 \mathrm{~cm}$ thick and exhibits an alternation of reddish Quaternary deposits and whitish cataclastic layers with irregular borders resembling fluidization textures typical of sedimentary flame structures. (d) 1225 Stereoplots of both non- and lineated fault and joints across the studied creek. Thick great circles 1226 are mean attitude of principal synthetic and antithetic fault strands, while dashed great circles represent mean orientation of the NE-SW striking tear faults (stereographic projection in the figure is equal area, lower hemisphere).

Figure 4. The Low Strain Damage Zone. (a-b) Typical field appearance of the Low Strain Damage 1231 Zone. This structural unit is affected mainly by fracturing, veining and subsidiary faulting. Original 1232 sedimentary features such as laminations, bedding surfaces and stylolites are easily recognizable. (c) Stereoplot of veins (poles) and joints (contours) in the Low Strain Damage Zone (stereographic 1234 projection in the figure is equal area, lower hemisphere). Here, deformation features are organized 1235 in sets typically synthetic and antithetic to the master fault. (d) Photomosaic in Move@ of the main 1236 outcrop of the Low Strain Damage Zone in the study area with line drawing of fractures and minor 1237 faults (red), major faults (yellow) and bedding (orange). (e) A large dolomite vein $1 \mathrm{~mm}$ thick 1238 (grey at BSE-SEM image) is cut by a $10 \mu \mathrm{m}$ thick calcite vein (white in color in the BSE-SEM 1239 image). 
1241 Figure 5. The High Strain Damage Zone. (a) Stereoplot of poles to joints in the High Strain

1242 Damage Zone shows fracturing related both to synthetic and antithetic faults and NE-SW striking 1243 faults (stereographic projection in the figure is equal area, lower hemisphere). (b) The presence of 1244 fracture sets closely spaced $(<1 \mathrm{~cm})$ typically isolates rock fragments of $1-2 \mathrm{~cm}$ in size. (c) Fracture 1245 traces perpendicular to the master fault. The frame dimension is $40 \times 60 \mathrm{~cm}$ and its attitude is $1246 \mathrm{~N} 292 / 66^{\circ}$. (d) Fracture traces parallel to the master fault. The frame dimension is $40 \mathrm{x} 60 \mathrm{~cm}$ and its 1247 attitude is $\mathrm{N} 204 / 74^{\circ}$.

Figure 6. The Breccia Unit. (a) Near faults the dolomite vein network becomes chaotic. Veins are up to 3-4 $\mathrm{cm}$ thick and have $<1 \mathrm{~m}$ lateral continuity. Minor faults cut through the breccia unit exploiting and dislocating the dolomite veins. (b) Inherited thrust fault juxtaposing the Calcare Massiccio Fm. onto the Verde Ammonitico Fm. exhibits reactivation as normal fault with fault-dragfold (on the right part) and development of S-C foliation bounding the fault plane (bottom left part). (c) Line drawing of (b). (d) Dolomite veins exploit preexisting discontinuities in the protolith, such as bedding surfaces (black arrows). (e) Stereoplot of veins (poles) and bedding (great circles) in the breccia unit (stereographic projection in the figure is equal area, lower hemisphere). (f) Where dolomite veining becomes pervasive, breccia clasts have irregular boundaries.

Figure 7. The Cataclastic Unit 2. (a) Typical field appearance of the Cataclastic Unit 2 with relicts of the protolith that are preserved (i.e., Verde Ammonitico Fm.). (b) Diffuse presence of dolomite 1261 and calcite veinlets in the Cataclastic Unit 2 with lateral continuity up to ten $\mathrm{cm}$ and aperture of 1262 about $5 \mathrm{~mm}$. (c) Stereoplot of poles to veins in the Cataclastic Unit 2. Veins have typically high dip angle $\left(>70^{\circ}\right.$ ) and are slightly clustered around a dip of $\mathrm{N} 0^{\circ}, \mathrm{N} 140^{\circ}$ and $\mathrm{N} 270^{\circ}$ (stereographic projection in the figure is equal area, lower hemisphere). (d) Microbreccias occur locally at the intersection of veins and consist of dolomite clasts embedded in a calcite matrix 5-10 $\mu \mathrm{m}$ in size 
1268 Figure 8. The Cataclastic Unit 1. (a) The Cataclastic Unit 1 is typically well cemented and cut by 1269 hundreds of minor faults with thin $(<2 \mathrm{~cm})$ ultracataclastic layers. (b) Decametric lithons of the CU2 embedded in the CU1. (c) Minor calcite veins (white at BSE-SEM image) cross-cut by Riedel shear fractures with low displacement $(<1 \mathrm{~mm})$. (d) Lineated mirror-like slip surfaces. (e) 1272 Deformation bands are sometimes observed within more granular cataclastic units. (f-g) Small rock 1273 volumes embedded within the CU1 are affected by intense fracturing (fracture spacing $<1 \mathrm{~mm}$ ) but lack significant shear deformation.

Figure 9. Microstructures of the highly localized sheared calcite veins. (a) The slipping zone records a succession of multiple vein deposition and then shearing, testified by calcite levels with different proportion of embedded dolomite matrix and internal microstructure. These has been interpreted as likely the expression of different strain accommodated by each calcite level. Here, the last vein precipitation event is preserved and characterized by polygonal calcite crystals up to 150 $1281 \mu \mathrm{m}$ in size and the presence of cavities. (b) Ultrafine grained calcite crystals (typical size of $1 \mu \mathrm{m}$ ) 1282 surround rounded micrometric dolomite clasts in high strain domains within sheared calcite veins. 1283 (c) The calcite matrix exhibits a foam texture. Calcite crystals have straight boundaries and triple 1284 junctions (some highlighted in red) are decorated by pores with size $<<1 \mu \mathrm{m}$. (d) Calcite veins in 1285 the slipping zone sharply truncating large dolomite clasts (see arrow). Occasionally, pockets of 1286 dolomite matrix are found preserved within the slipping zone. (e) Minor conjugate high-angle 1287 sheared fractures cut and dislocate the PSS. All images are BSE-SEM.

1289 Figure 10. Microstructures of non-foliated cataclasites. (a) Slipping zone grading from cataclasite 1290 to ultracataclasite towards the slip surface (top of the image, OM). (b) Extended plagues of calcite 1291 cement may occur as infilling of pores within the dolomite matrix (BSE-SEM image). (c) In-situ 1292 shattering in the VCFZ. Dolomite clasts are radially fractured and lack of evidence of shearing; they 
are interpreted as "exploded" (OM image). (d) In the in-situ shattered rocks, the dolomite matrix consists of angular clasts, less than $10 \mu \mathrm{m}$ in size, which underwent grain size reduction by splitting (BSE-SEM image). (e) Mirror-like slip surface truncating dolostone clasts embedded in a very fine dolomite matrix (OM image).

Figure 11. Microstructures of foliated cataclasites and cataclastic bands. (a) Foliated cataclasite with layering of calcite- and dolomite-rich bands. Layers are organized in a S-C type foliation, consistent with the direction of shear. Elongated "tails" of fine dolomite and calcite crystals are observed around big dolomite and calcite clasts (about $200 \mu \mathrm{m}$ in size). The slip surface cuts abruptly the foliated cataclasite. (b) Foam texture in the deformed calcite matrix, similar to the one observed in the highly localized sheared calcite veins (Fig. 9c). (c) Irregular wavy boundaries between the calcite-rich domains and dolomite dominated areas in the foliated ultracataclasites. (d) Injection of calcite cement-supported ultracataclasite (comprising mostly grains from the Quaternary deposits) in the dolomite-rich ultracataclasite (i.e., CU1). (e-f) The contact between the shattered cataclasite and the cataclastic band is sharp and characterized by an increase in the fine part in the matrix. All images are BSE-SEM.

Figure 12. Conceptual model for the formation of the cataclastic unit. (a-b) The propagation of seismic ruptures along the master fault result in the formation of a comminuted in-situ shattered dolostone band. The presence of a host rock already damaged allows in-situ shattering to occur at lower strain rates to those expected for the same intact rock (Doan and d'Hour, 2012). (c) Localization in the in-situ shattered dolostone along the master fault and subsidiary faults leads to grain rotation, matrix development and obliteration of the host rock original sedimentary features. Eventually calcite-rich fluids percolate and cement the cataclastic band. (d) The cataclastic unit widens as it records multiple cycles of seismic rupture propagation - in-situ shattering localization - cementation. The conceptual model is based on the interpretation of the exposures of 
1319 the footwall of the VCFZ. Given the absence of outcrops of the hangingwall, the deformation has 1320 only been inferred and colored in light gray.

1322 Figure 13. Earthquake distribution in the L'Aquila 2009 seismic sequence. (a) Map of the relocated 1323 earthquakes for the L'Aquila 2009 seismic sequence (modified after Valoroso et al., 2013). Red 1324 dots: foreshocks; black dots: aftershocks; red stars: main earthquakes; green lines: active mapped 1325 faults; yellow lines: co-seismic surface ruptures. GSFS is Gran Sasso Fault System. (b) Vertical 1326 section of aftershocks distribution at depth with seismotectonic model of the area (modified after 1327 Valoroso et al., 2013). The low-angle plane was interpreted as a shallow flat portion of a thrust 1328 reactivated as normal fault during the seismic sequence. (c) Map of lineaments from the geological 1329 map in Fig. 1b in the study area. (d) Simplified geological section from Fig. 2b evidencing the 1330 major faults within the studied creek. Note the similarity of the fault network, at smaller scale, with 1331 the vertical cross section shown in Fig. $13 b$. 

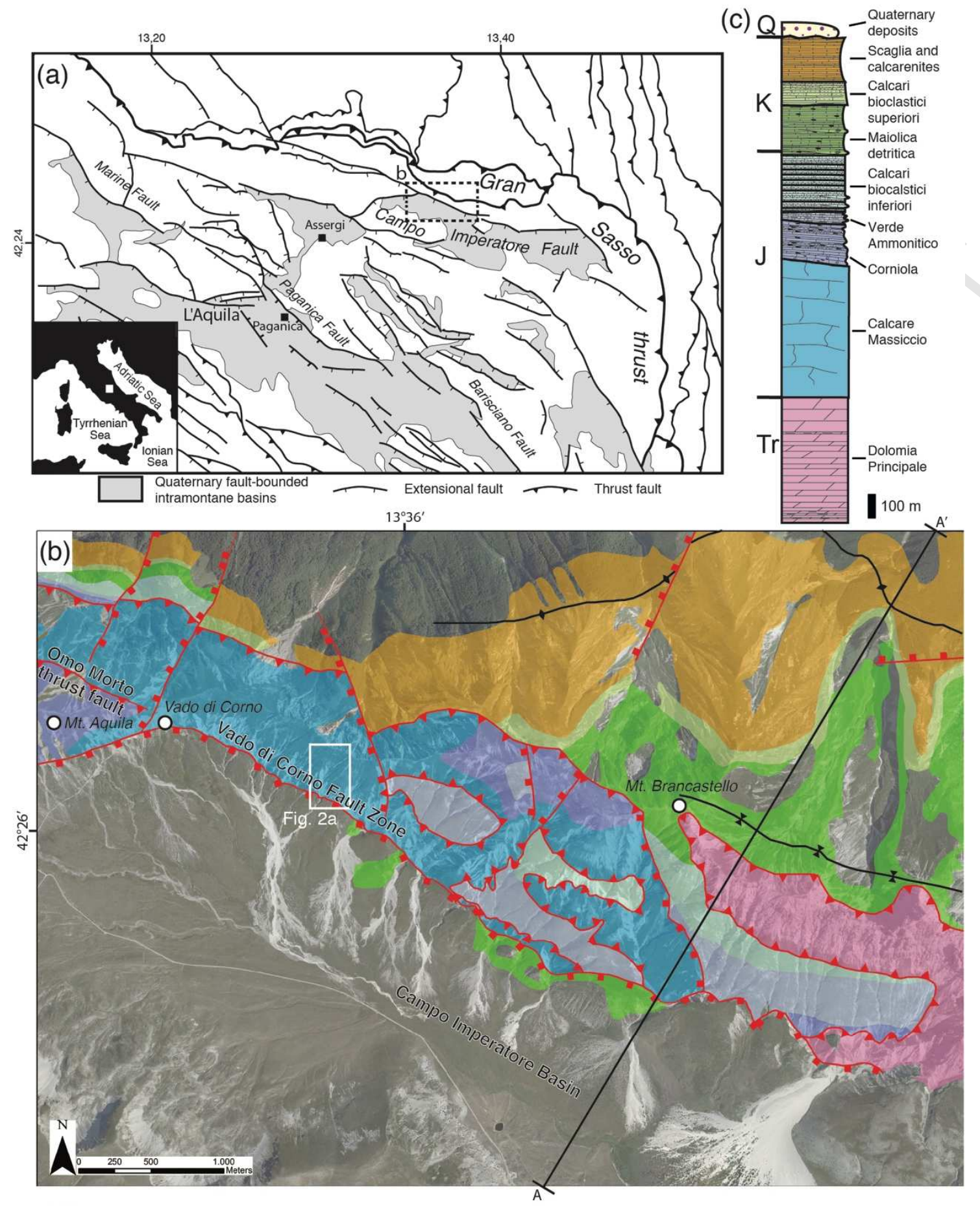

(d)

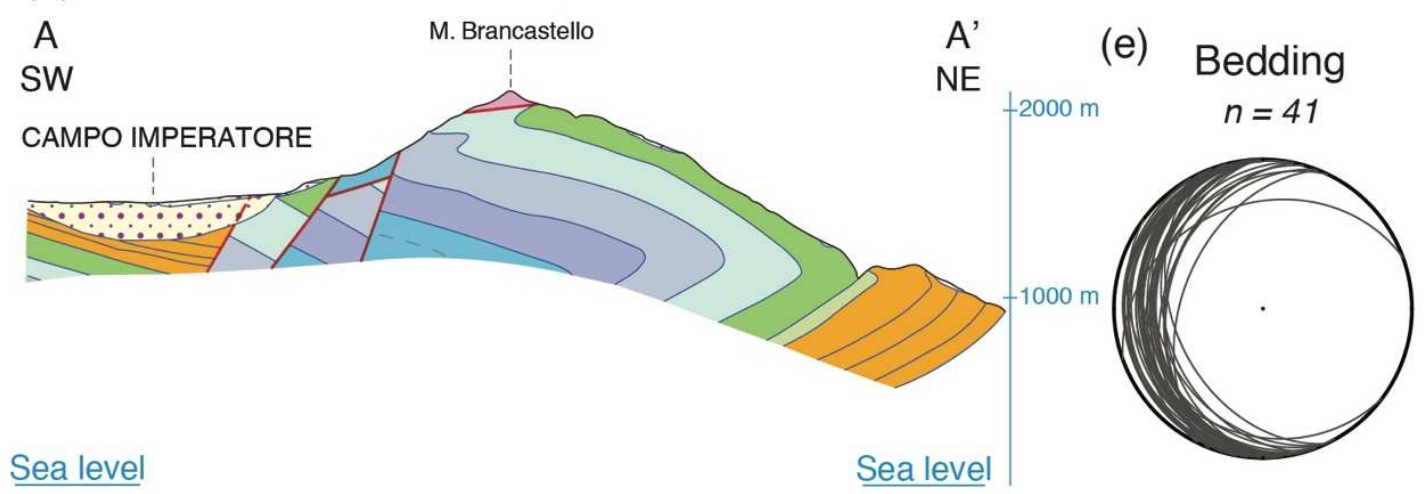


Figure 1. Geological setting of the Campo Imperatore area. (a) Structural map of the Gran Sasso area (modified after Storti et al., 2013). (b) Geological map of the study area simplified after the published Foglio 349 "Gran Sasso d'Italia" (Ispra, 2012). Quaternary colluvial deposits are the infilling of the Campo Imperatore intramontane basin and correspond to the non-colored areas. NNE-SSW striking normal faults dissect and displace the thrust system. The Omo Morto thrust fault runs on the northern side of Mt. Aquila and disappears before Vado di Corno, where the fault zone (VCFZ) is exposed within badlands. (c) Stratigraphic column of the Campo Imperatore area (modified after Cardello and Doglioni, 2014). (d) Geological cross section across the Campo Imperatore intramontane basin (modified after Ispra, 2012). To the NE of the Mt. Brancastello strata at the hangingwall of the thrust are overturned, while in the Campo Imperatore plain normal faults cut and dislocate the thrust system. (e) Stereographic projection of bedding surfaces measured within the VCFZ result in a monocline with constant attitude of $\mathrm{N} 270 / 20^{\circ}$ (stereographic projection in the figure is equal area, lower hemisphere). 


\section{ACCEPTED MANUSCRIPT}

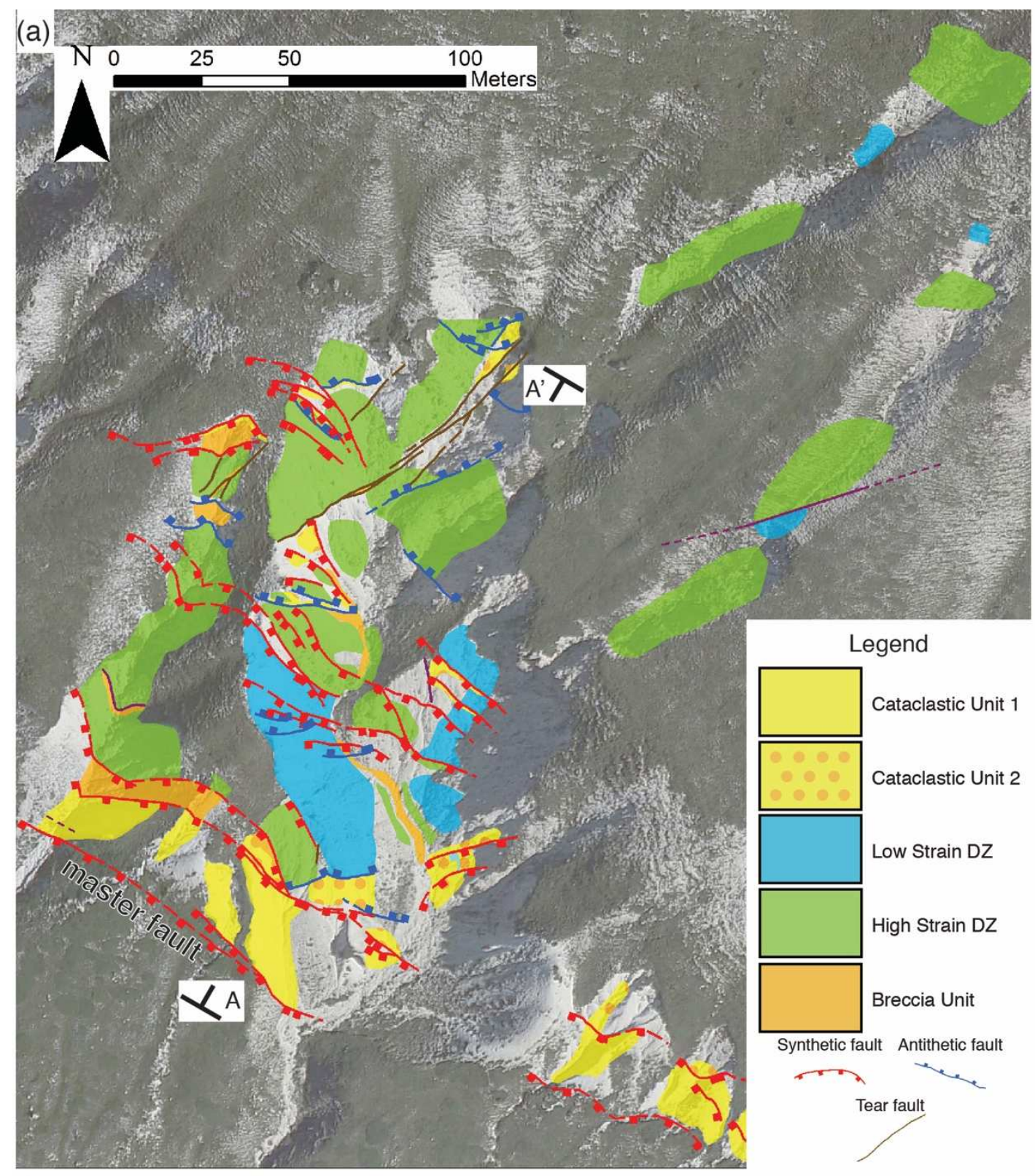

(b)

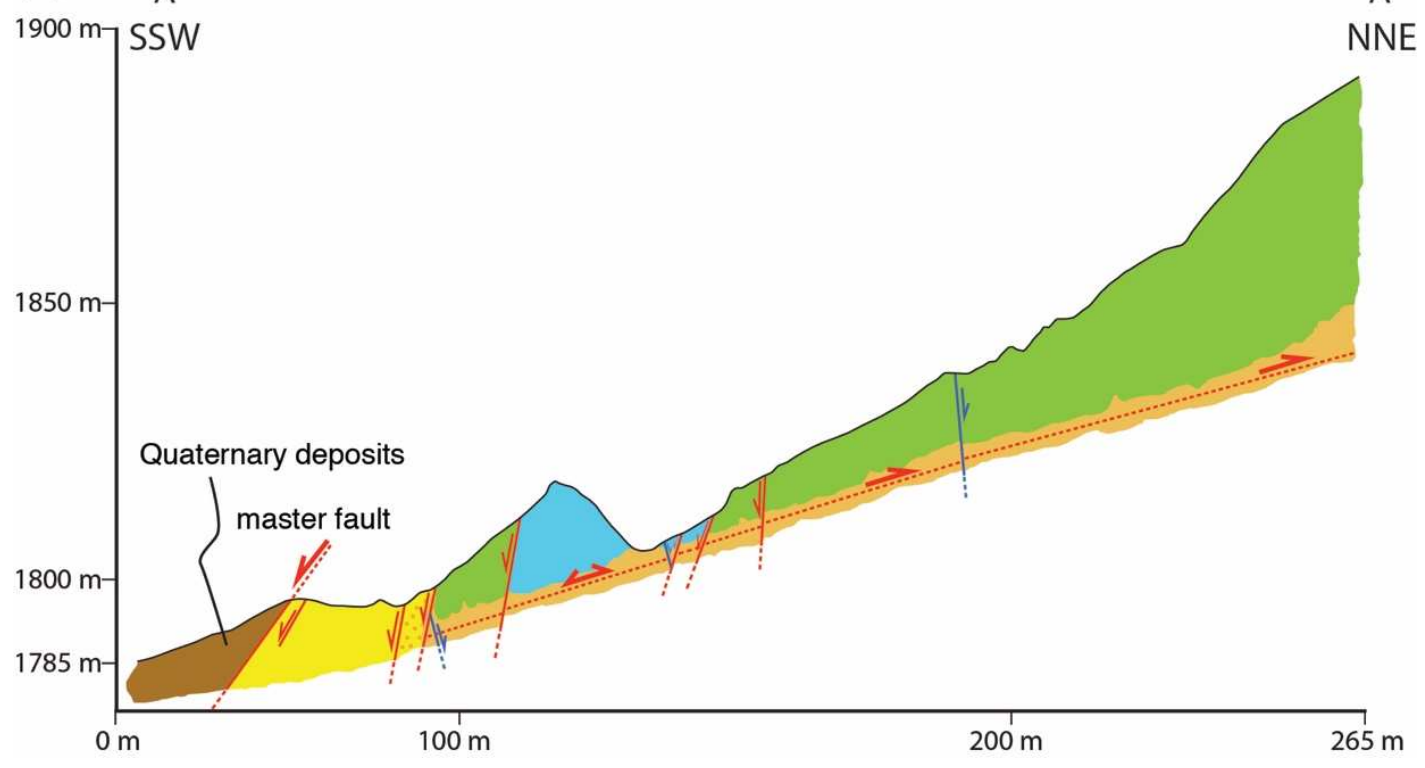


Figure 2. Structural map and geological section of the study area. (a) The structural map shows the distribution of principal fault strands (ticks on faults are drawn on the downthrown side) and structural units distinguished within the footwall block of the Vado di Corno Fault Zone. The base of the creek is marked by the master fault, which is lined by the cataclastic units. A tens of meters thick lithon of Low Strain Damage Zone is found at about $50 \mathrm{~m}$ from the master fault. The Breccia Unit outcrops both at the bottom of the creek in the center of the map and in contact with the Cataclastic Unit 1 to the SW. The High Strain Damage Zone comprises most of the fault zone in terms of rock volumes. (b) A geological section oriented orthogonal to the master fault $\left(\mathrm{N} 30^{\circ} \mathrm{E}\right)$ shows how the structural units are typically associated and bounded by the normal faults with the exception of the Breccia Unit, which dips at low angle and outcrops where the creek is more eroded. The axes are in scale $\mathrm{X}: \mathrm{Y}=1: 2$. 


\section{ACCEPTED MANUSCRIPT}

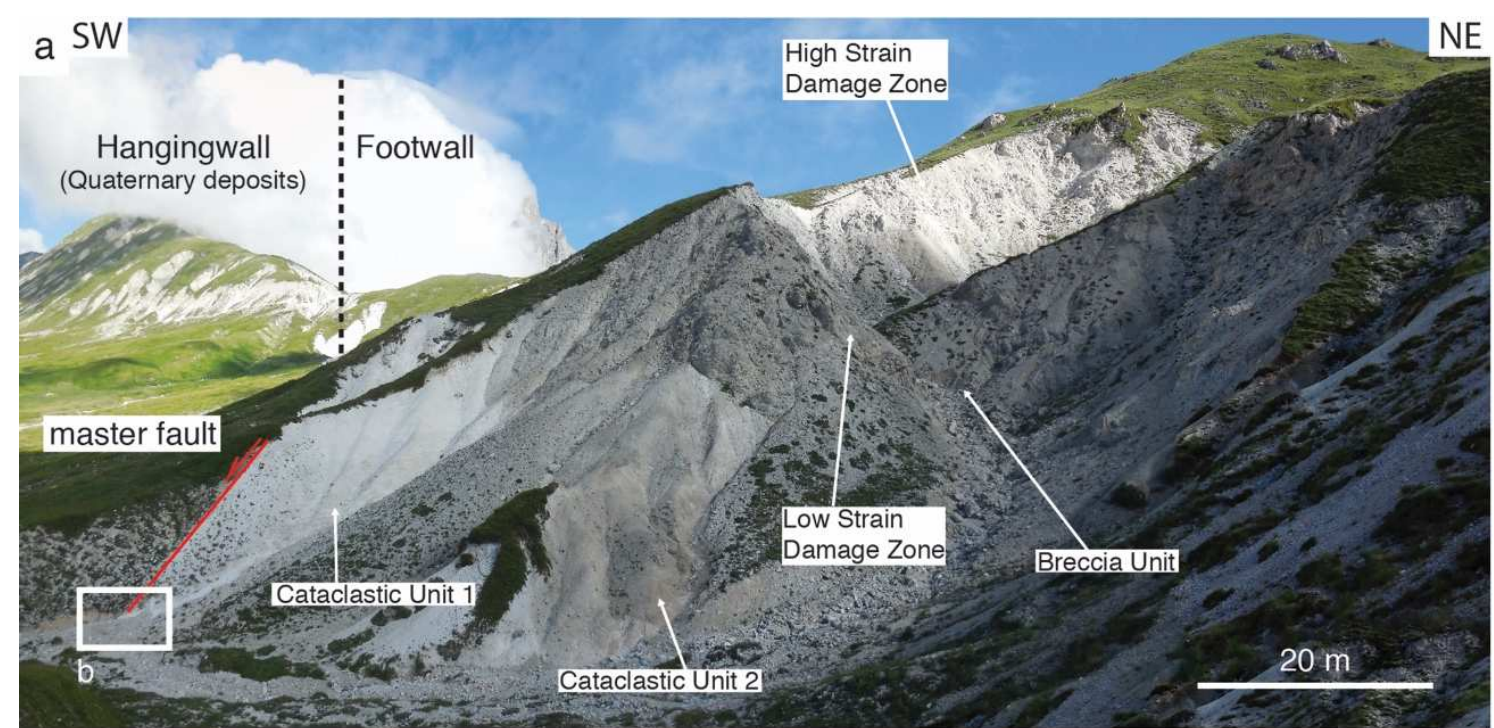

C
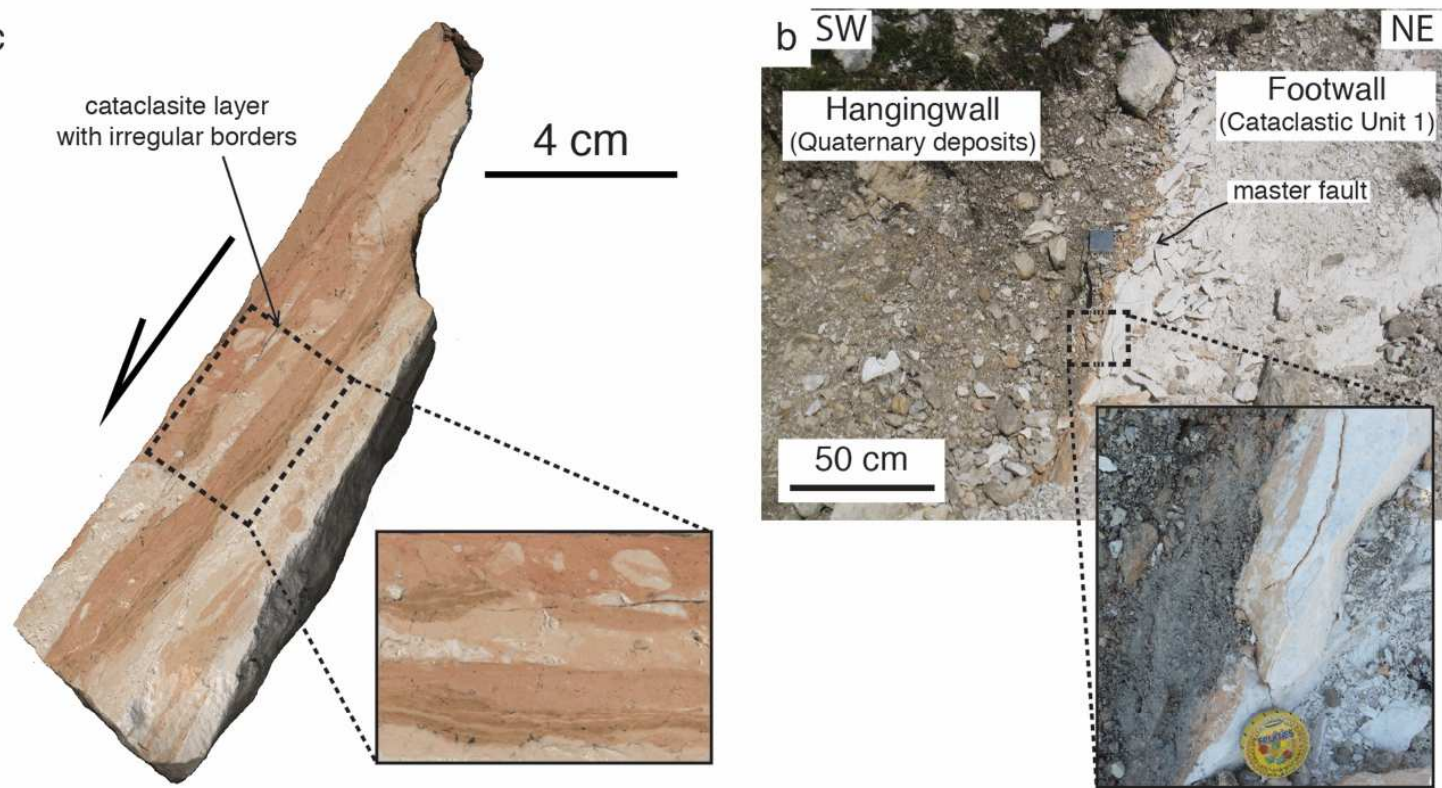

d

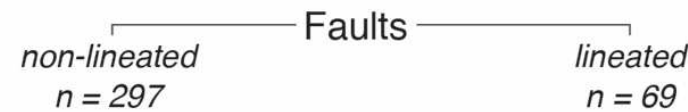

Joints

$n=297$

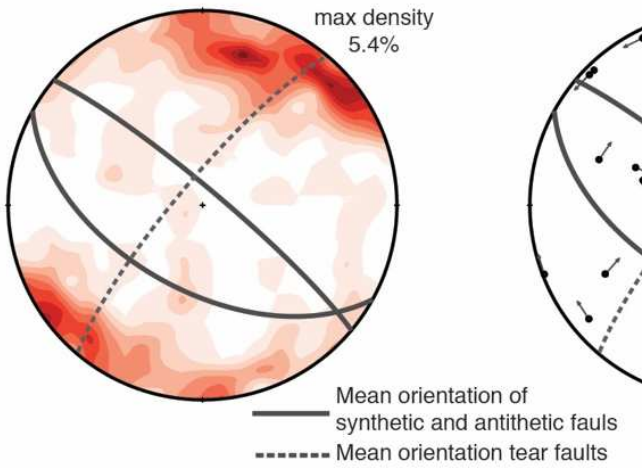

$n=69$

$n=609$

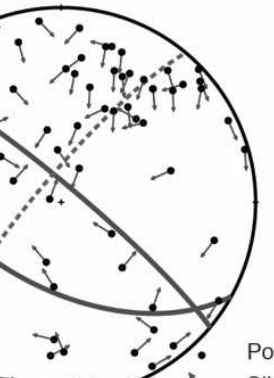

Pole to faults

Slip vector to pole

Mean orientation of

synthetic and antithetic fauls

-..---- Mean orientation tear faults

Figure 3. Core of the Vado di Corno Fault Zone. (a) The structural units distinguished in the footwall block of the VCFZ show a great variability in appearance due to changes in the bulk deformation intensity and deformation processes. (b) The base of the badlands is marked by the 
contact between the Quaternary deposits in the hangingwall (reddish in color) and the cataclasites in the footwall (white in color) along the master fault. (c) The core of the master fault is $<20 \mathrm{~cm}$ thick and exhibits an alternation of reddish Quaternary deposits and whitish cataclastic layers with irregular borders resembling fluidization textures typical of sedimentary flame structures. (d) Stereoplots of both non- and lineated fault and joints across the studied creek. Thick great circles are mean attitude of principal synthetic and antithetic fault strands, while dashed great circles represent mean orientation of the NE-SW striking tear faults (stereographic projection in the figure is equal area, lower hemisphere). 


\section{ACCEPTED MANUSCRIPT}
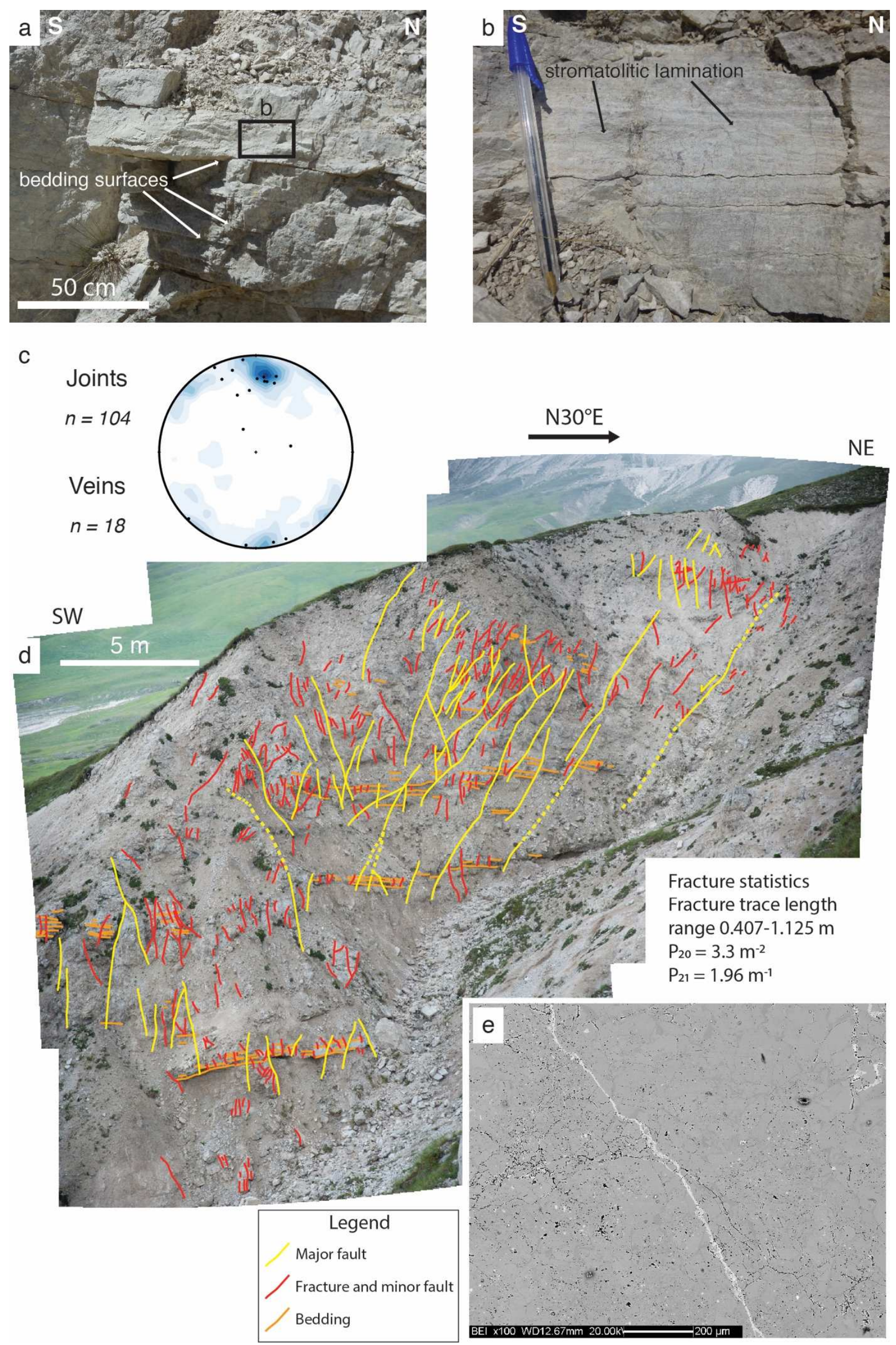
Figure 4. The Low Strain Damage Zone. (a-b) Typical field appearance of the Low Strain Damage Zone. This structural unit is affected mainly by fracturing, veining and subsidiary faulting. Original sedimentary features such as laminations, bedding surfaces and stylolites are easily recognizable. (c) Stereoplot of veins (poles) and joints (contours) in the Low Strain Damage Zone (stereographic projection in the figure is equal area, lower hemisphere). Here, deformation features are organized in sets typically synthetic and antithetic to the master fault. (d) Photomosaic in Move $\odot$ of the main outcrop of the Low Strain Damage Zone in the study area with line drawing of fractures and minor faults (red), major faults (yellow) and bedding (orange). (e) A large dolomite vein $\sim 1 \mathrm{~mm}$ thick (grey at BSE-SEM image) is cut by a $10 \mu \mathrm{m}$ thick calcite vein (white in color in the BSE-SEM image). 
a
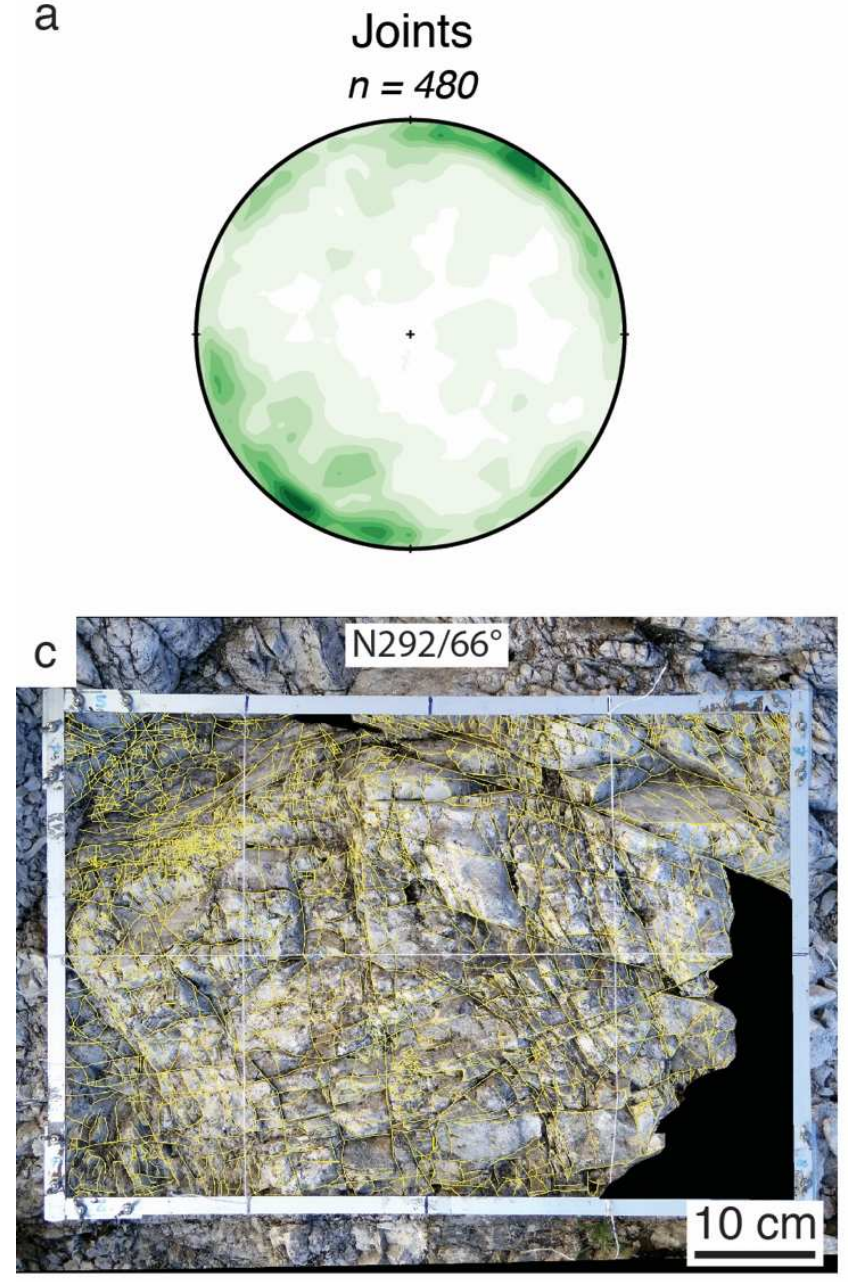

Fracture statistics

Fracture trace length range $1-10 \mathrm{~cm}$

$$
\begin{gathered}
P_{20}=5170 \mathrm{~m}^{-2} \\
P_{21}=124.454 \mathrm{~m}^{-1}
\end{gathered}
$$
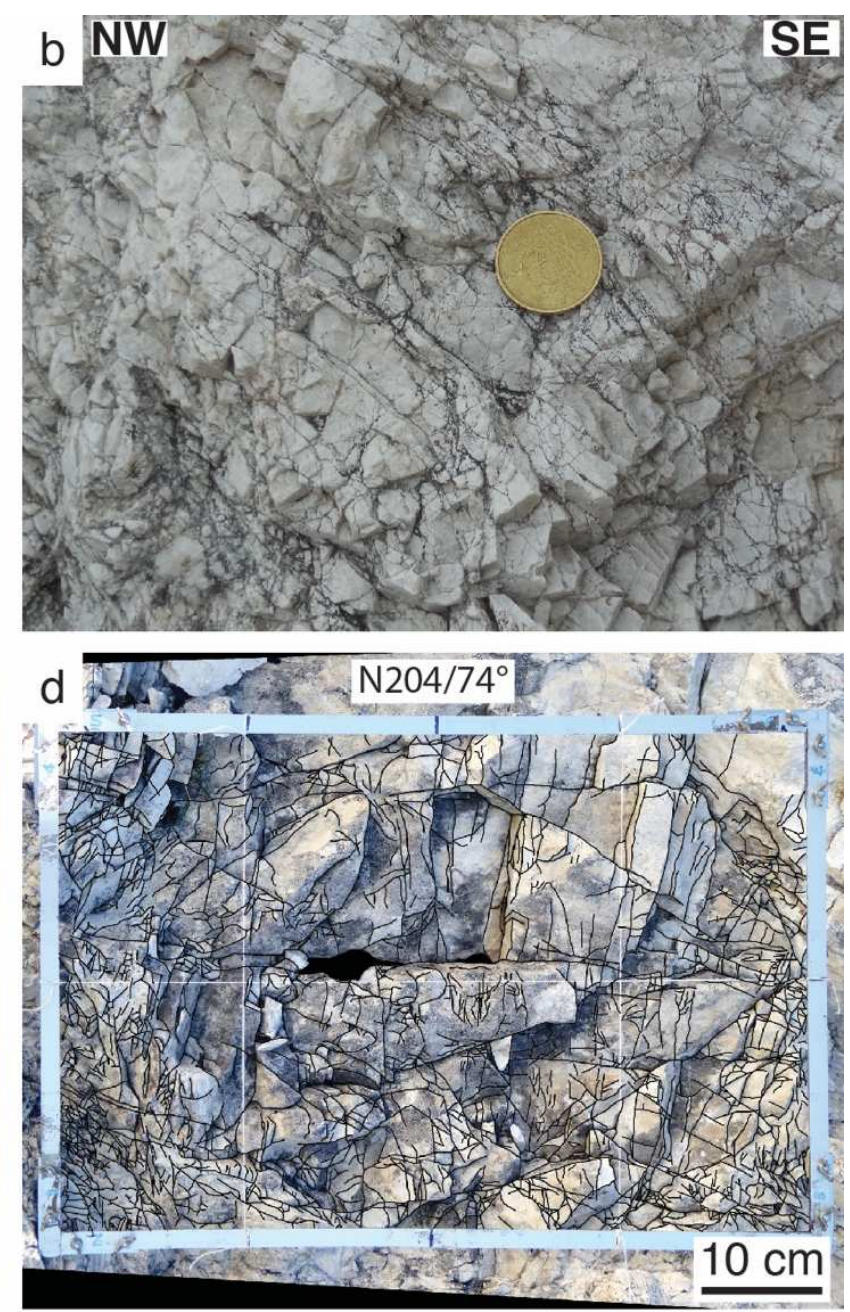

Fracture statistics

Fracture trace length range $1-10 \mathrm{~cm}$

$$
\mathrm{P}_{20}=5107 \mathrm{~m}^{-2}
$$$$
\mathrm{P}_{21}=118.377 \mathrm{~m}^{-1}
$$

Figure 5. The High Strain Damage Zone. (a) Stereoplot of poles of joints in the High Strain

Damage Zone shows fracturing related both to synthetic and antithetic faults and NE-SW striking faults (stereographic projection in the figure is equal area, lower hemisphere). (b) The presence of fracture sets closely spaced $(<1 \mathrm{~cm})$ typically isolates rock fragments of $1-2 \mathrm{~cm}$ in size. (c) Fracture traces perpendicular to the master fault. The frame dimension is $40 \mathrm{x} 60 \mathrm{~cm}$ and its attitude is $\mathrm{N} 292 / 66^{\circ}$. (d) Fracture traces parallel to the master fault. The frame dimension is $40 \mathrm{x} 60 \mathrm{~cm}$ and its attitude is $\mathrm{N} 204 / 74^{\circ}$. 

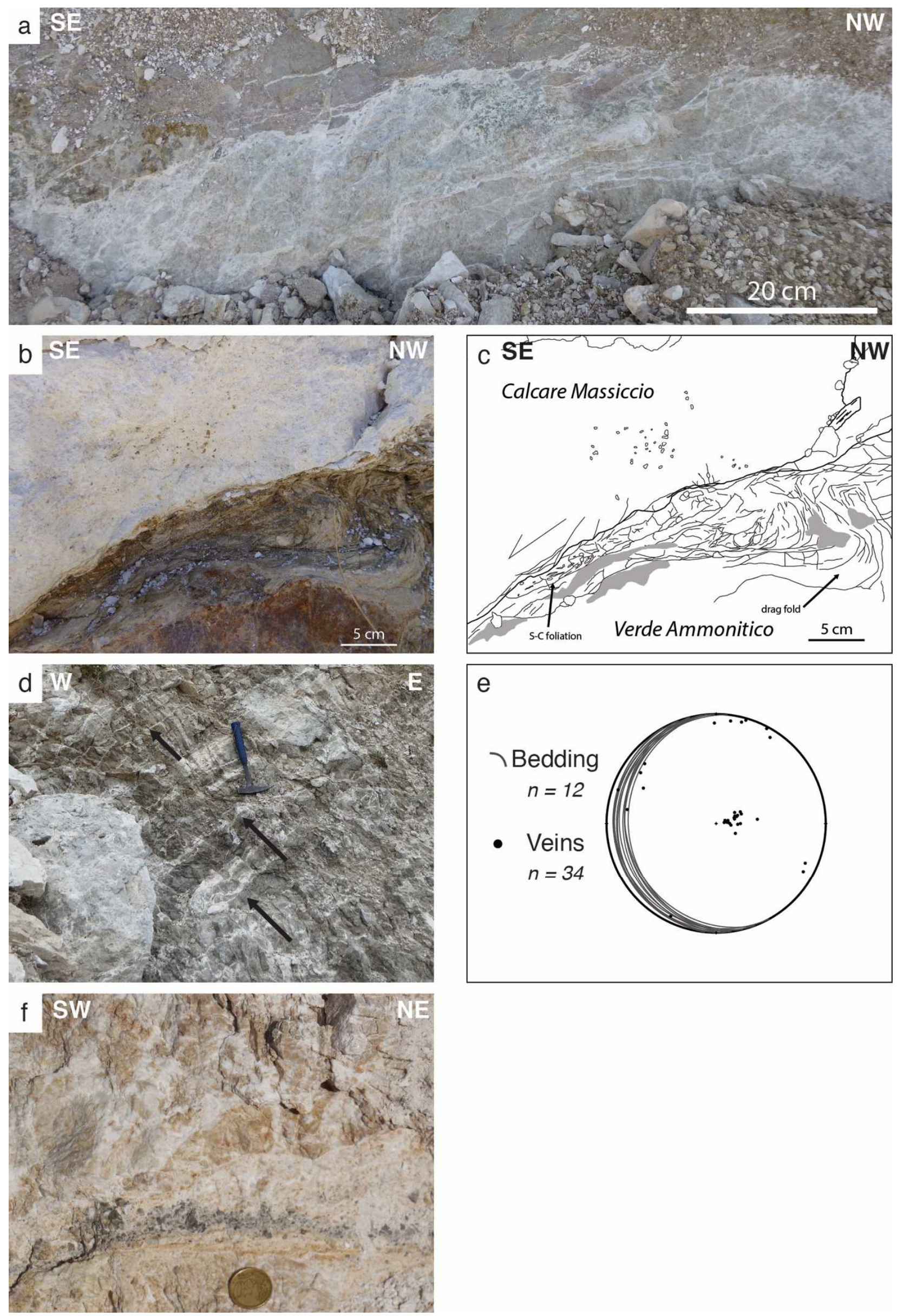
Figure 6. The Breccia Unit. (a) Near faults the dolomite vein network becomes chaotic. Veins are up to 3-4 $\mathrm{cm}$ thick and have $<1 \mathrm{~m}$ lateral continuity. Minor faults cut through the breccia unit exploiting and dislocating the dolomite veins. (b) Inherited thrust fault juxtaposing the Calcare Massiccio Fm. onto the Verde Ammonitico Fm. exhibits reactivation as normal fault with fault-dragfold (on the right part) and development of S-C foliation bounding the fault plane (bottom left part). (c) Line drawing of (b). (d) Dolomite veins exploit preexisting discontinuities in the protolith, such as bedding surfaces (black arrows). (e) Stereoplot of veins (poles) and bedding (great circles) in the breccia unit (stereographic projection in the figure is equal area, lower hemisphere). (f) Where dolomite veining becomes pervasive, breccia clasts have irregular boundaries. 


\section{ACCEPTED MANUSCRIPT}
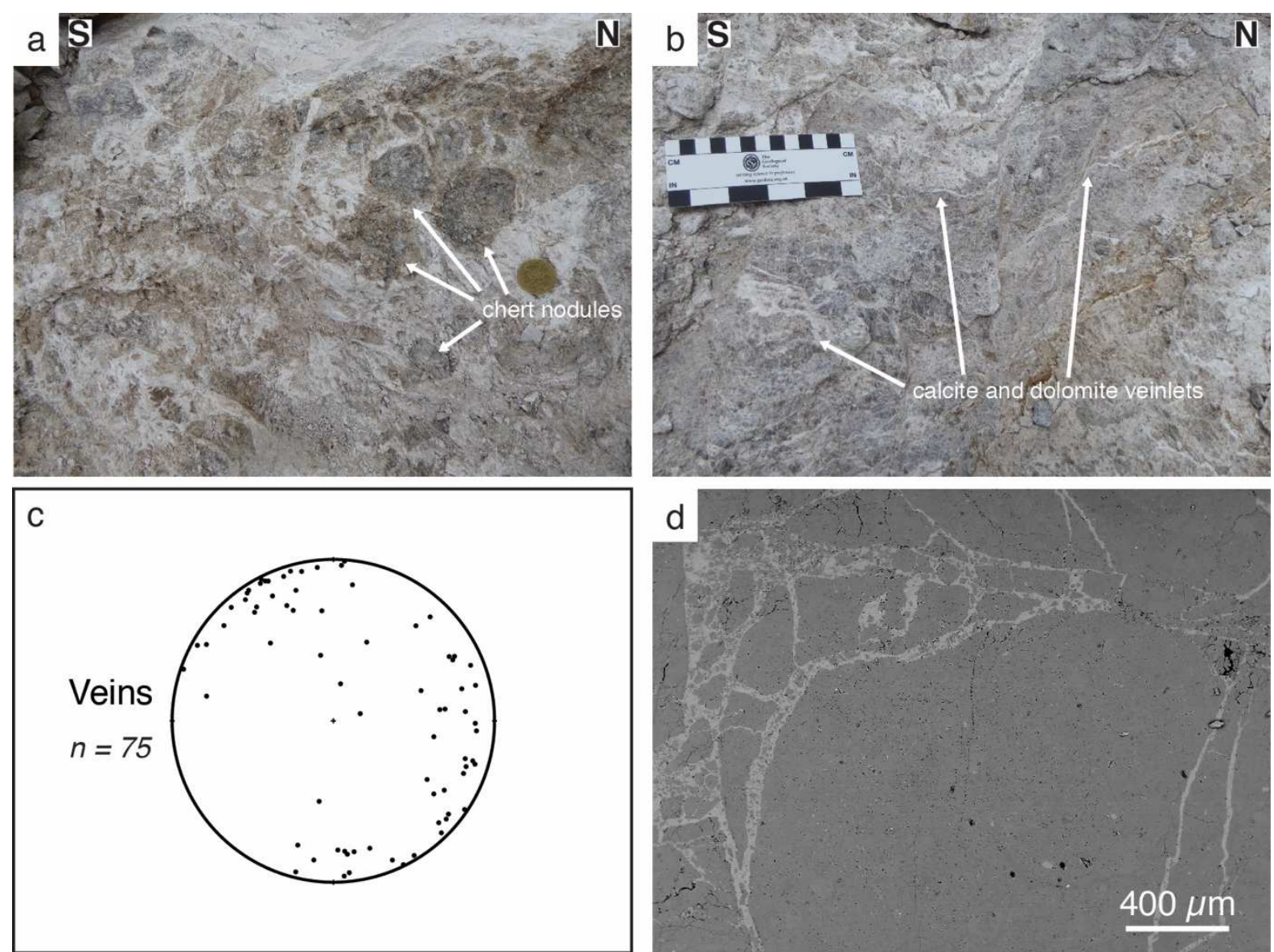

Figure 7. The Cataclastic Unit 2. (a) Typical field appearance of the Cataclastic Unit 2 with relicts of the protolith that are preserved (i.e., Verde Ammonitico Fm.). (b) Diffuse presence of dolomite and calcite veinlets in the Cataclastic Unit 2 with lateral continuity up to ten $\mathrm{cm}$ and aperture of about $5 \mathrm{~mm}$. (c) Stereoplot of poles to veins in the Cataclastic Unit 2. Veins have typically high dip angle $\left(>70^{\circ}\right)$ and are slightly clustered around a dip of $\mathrm{N} 0^{\circ}, \mathrm{N} 140^{\circ}$ and $\mathrm{N} 270^{\circ}$ (stereographic projection in the figure is equal area, lower hemisphere). (d) Microbreccias occur locally at the intersection of veins and consist of dolomite clasts embedded in a calcite matrix $5-10 \mu \mathrm{m}$ in size (BSE-SEM image). 


\section{ACCEPTED MANUSCRIPT}
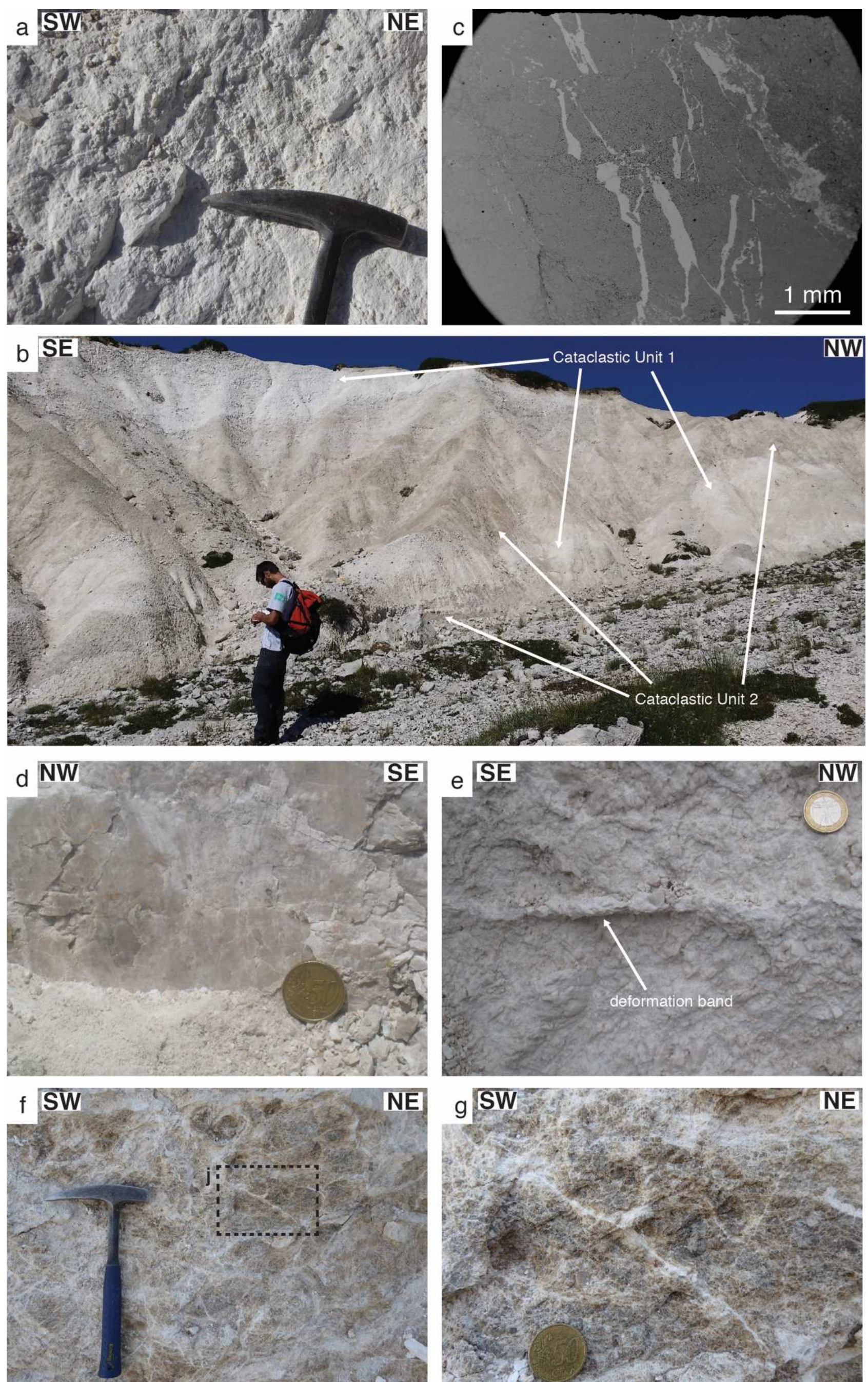
Figure 8. The Cataclastic Unit 1. (a) The Cataclastic Unit 1 is typically well cemented and cut by hundreds of minor faults with thin $(<2 \mathrm{~cm})$ ultracataclastic layers. (b) Decametric lithons of the CU2 embedded in the CU1. (c) Minor calcite veins (white at BSE-SEM image) cross-cut by Riedel shear fractures with low displacement $(<1 \mathrm{~mm})$. (d) Lineated mirror-like slip surfaces. (e) Deformation bands are sometimes observed within more granular cataclastic units. (f-g) Small rock volumes embedded within the CU1 are affected by intense fracturing (fracture spacing $<1 \mathrm{~mm}$ ) but lack significant shear deformation. 


\section{ACCEPTED MANUSCRIPT}
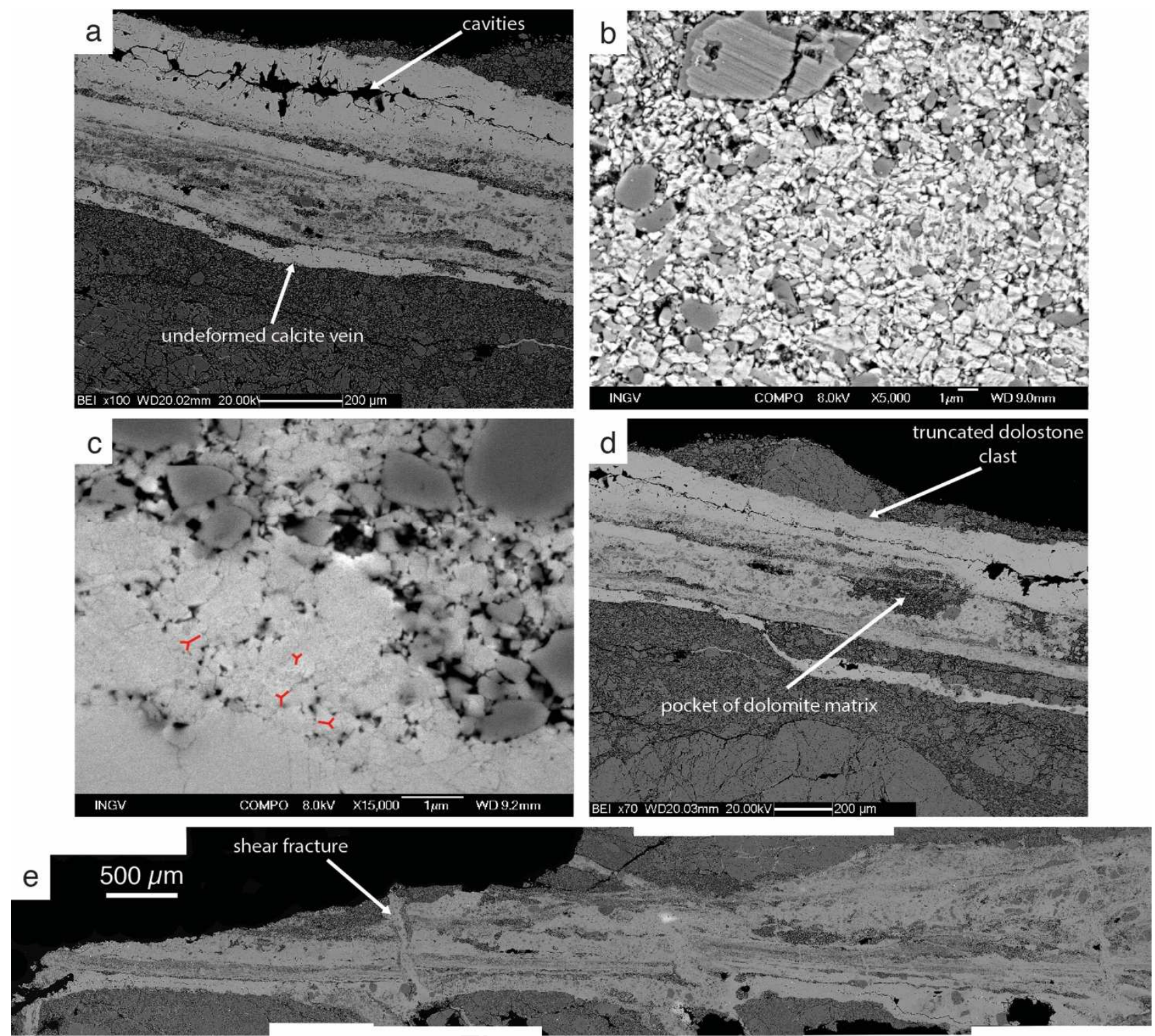

Figure 9. Microstructures of the highly localized sheared calcite veins. (a) The slipping zone

records a succession of multiple vein deposition and then shearing, testified by calcite levels with different proportion of embedded dolomite matrix and internal microstructure. These has been interpreted as likely the expression of different strain accommodated by each calcite level. Here, the last vein precipitation event is preserved and characterized by polygonal calcite crystals up to 150 $\mu \mathrm{m}$ in size and the presence of cavities. (b) Ultrafine grained calcite crystals (typical size of $1 \mu \mathrm{m}$ ) surround rounded micrometric dolomite clasts in high strain domains within sheared calcite veins. (c) The calcite matrix exhibits a foam texture. Calcite crystals have straight boundaries and triple junctions (some highlighted in red) are decorated by pores with size $\ll<1 \mu \mathrm{m}$. (d) Calcite veins in the slipping zone sharply truncating large dolomite clasts (see arrow). Occasionally, pockets of 
dolomite matrix are found preserved within the slipping zone. (e) Minor conjugate high-angle sheared fractures cut and dislocate the PSS. All images are BSE-SEM. 

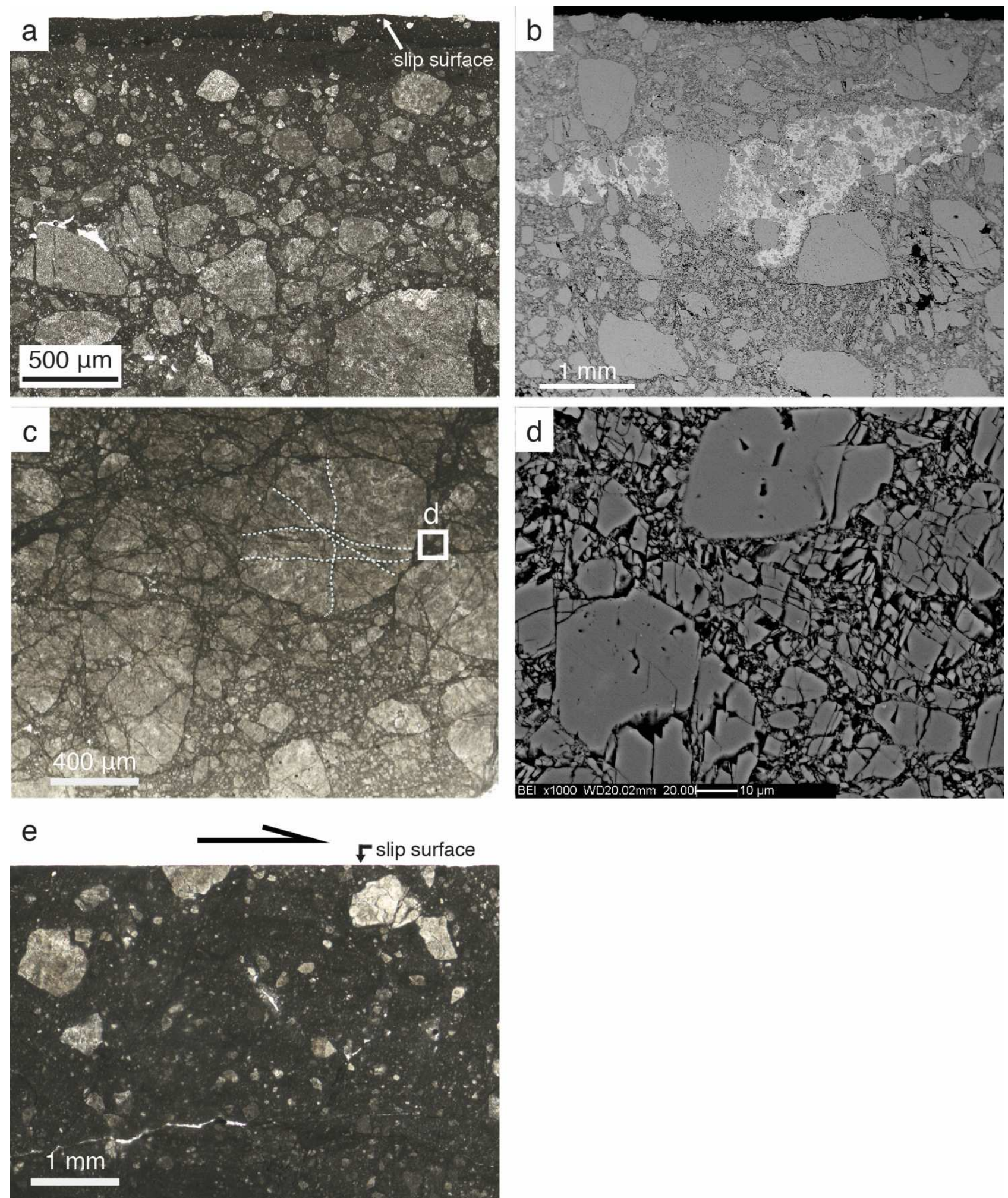

Figure 10. Microstructures of non-foliated cataclasites. (a) Slipping zone grading from cataclasite to ultracataclasite towards the slip surface (top of the image, OM). (b) Extended plagues of calcite cement may occur as infilling of pores within the dolomite matrix (BSE-SEM image). (c) In-situ shattering in the VCFZ. Dolomite clasts are radially fractured and lack of evidence of shearing; they are interpreted as "exploded" (OM image). (d) In the in-situ shattered rocks, the dolomite matrix 
consists of angular clasts, less than $10 \mu \mathrm{m}$ in size, which underwent grain size reduction by splitting (BSE-SEM image). (e) Mirror-like slip surface truncating dolostone clasts embedded in a very fine dolomite matrix (OM image). 


\section{ACCEPTED MANUSCRIPT}
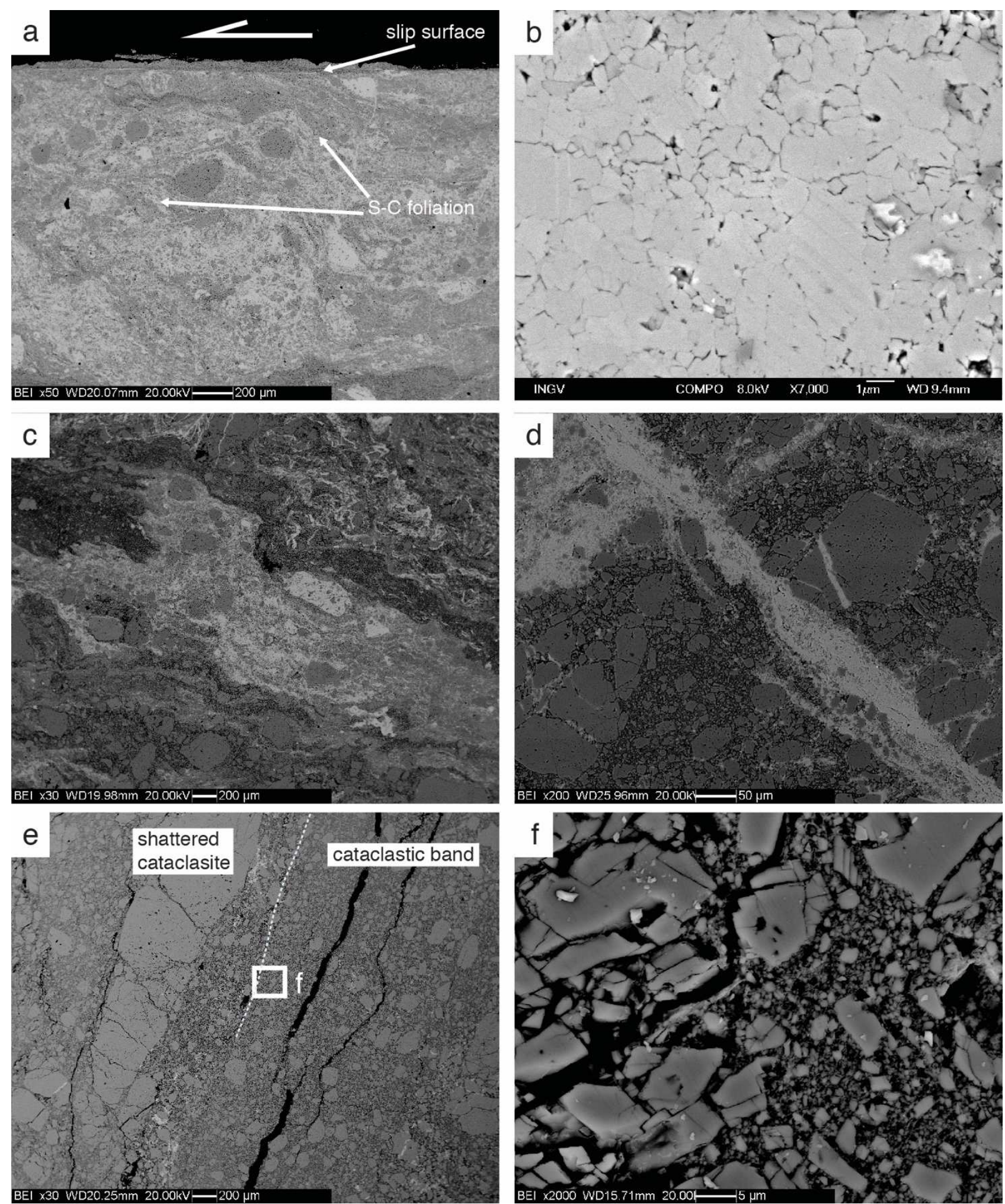

Figure 11. Microstructures of foliated cataclasites and cataclastic bands. (a) Foliated cataclasite

with layering of calcite- and dolomite-rich bands. Layers are organized in a S-C type foliation, consistent with the direction of shear. Elongated "tails" of fine dolomite and calcite crystals are observed around big dolomite and calcite clasts (about $200 \mu \mathrm{m}$ in size). The slip surface cuts abruptly the foliated cataclasite. (b) Foam texture in the deformed calcite matrix, similar to the one 
observed in the highly localized sheared calcite veins (Fig. 9c). (c) Irregular wavy boundaries between the calcite-rich domains and dolomite dominated areas in the foliated ultracataclasites. (d) Injection of calcite cement-supported ultracataclasite (comprising mostly grains from the Quaternary deposits) in the dolomite-rich ultracataclasite (i.e., CU1). (e-f) The contact between the shattered cataclasite and the cataclastic band is sharp and characterized by an increase in the fine part in the matrix. All images are BSE-SEM. 
(a)

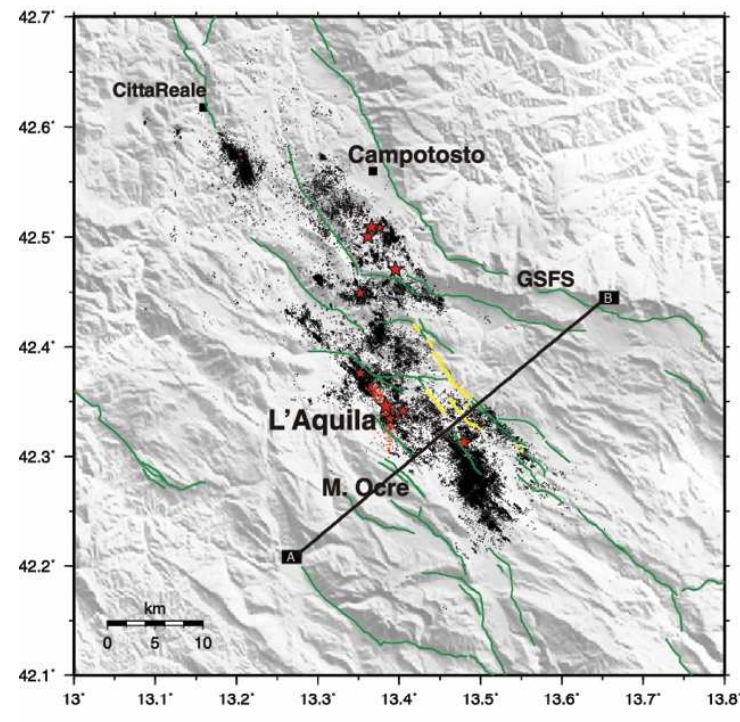

(c)

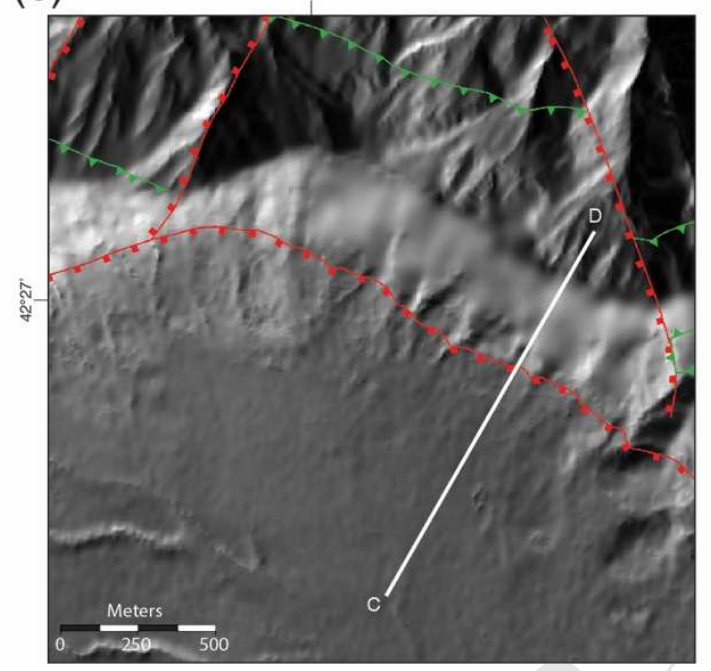

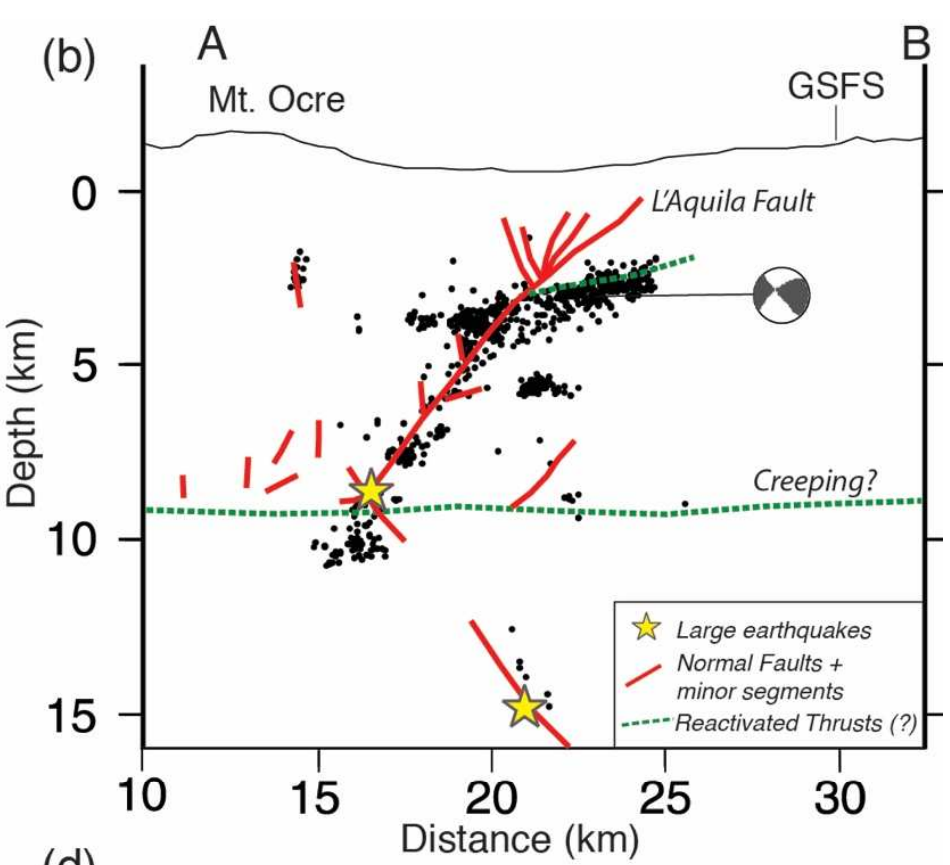

(d)

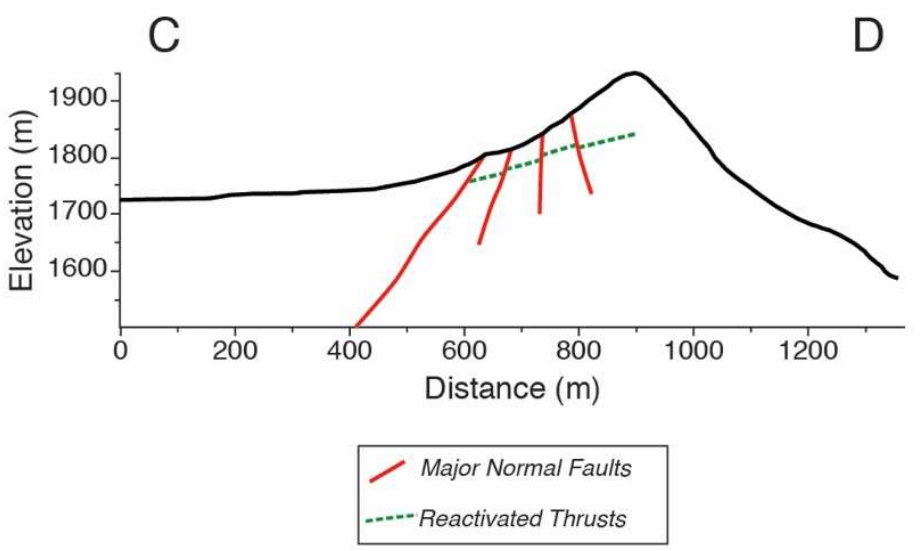

Figure 12. Earthquake distribution in the L'Aquila 2009 seismic sequence. (a) Map of the relocated earthquakes for the L'Aquila 2009 seismic sequence (modified after Valoroso et al., 2013). Red dots: foreshocks; black dots: aftershocks; red stars: main earthquakes; green lines: active mapped faults; yellow lines: co-seismic surface ruptures. GSFS is Gran Sasso Fault System. (b) Vertical section of aftershocks distribution at depth with seismotectonic model of the area (modified after Valoroso et al., 2013). The low-angle plane was interpreted as a shallow flat portion of a thrust reactivated as normal fault during the seismic sequence. (c) Map of lineaments from the geological map in Fig. 1b in the study area. (d) Simplified geological section from Fig. 2b evidencing the major faults within the studied creek. Note the similarity of the fault network, at smaller scale, with the vertical cross section shown in Fig. $12 b$. 

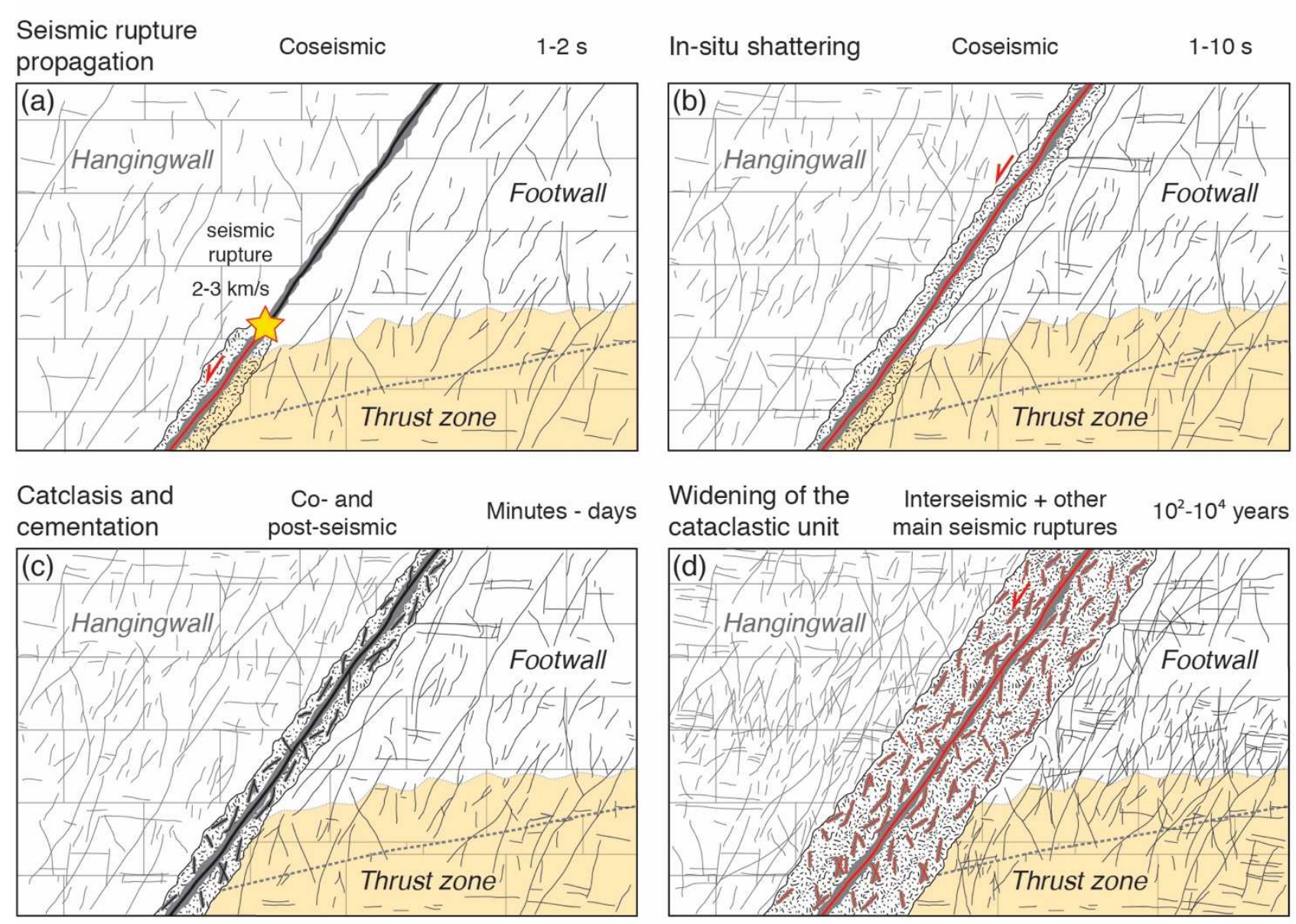

$\hat{W}$ Seismic rupture tip / Active fault

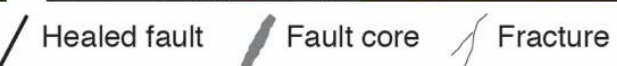

Figure 12. Conceptual model for the formation of the cataclastic unit. (a-b) The propagation of seismic ruptures along the master fault result in the formation of a comminuted in-situ shattered dolostone band. The presence of a host rock already damaged allows in-situ shattering to occur at lower strain rates to those expected for the same intact rock (Doan and d'Hour, 2012). (c) Localization in the in-situ shattered dolostone along the master fault and subsidiary faults leads to grain rotation, matrix development and obliteration of the host rock original sedimentary features. Eventually calcite-rich fluids percolate and cement the cataclastic band. (d) The cataclastic unit widens as it records multiple cycles of seismic rupture propagation - in-situ shattering localization - cementation. The conceptual model is based on the interpretation of the exposures of the footwall of the VCFZ. Given the absence of outcrops of the hangingwall, the deformation has only been inferred and colored in light gray. 


\section{Highlights}

- Fault rock distribution of the VCFZ footwall-block was mapped in detail

- Evidence of extensional reactivation of an older thrust zone was documented

- Thick cataclastic bands are suggested to form by pulverization and cataclasis

- Microstructural investigations testified the past seismicity of the VCFZ

- Fault structure resembles the fault network activated by L'Aquila 2009 earthquake 